\title{
Benthic Macroalgal Blooms as Indicators of Nutrient Loading from Aquifer-Injected Sewage Effluent in Environmentally Sensitive Near-Shore Waters Associated with the South Florida Keys
}

\author{
Sydney T. Bacchus ${ }^{1}$, Sergio Bernardes ${ }^{1}$, Thomas Jordan ${ }^{1} \&$ Marguerite Madden ${ }^{1}$ \\ ${ }^{1}$ Center for Geospatial Research, Department of Geography, University of Georgia, Athens, Georgia \\ 30602-2502 USA \\ Correspondence: Marguerite Madden, Center for Geospatial Research, Department of Geography, University of \\ Georgia, Athens, Georgia 30602-2502, USA. E-mail: mmadden@uga.edu
}

Received: September 12, 2014

doi:10.5539/jgg.v6n4p164
Accepted: September 25, 2014 Online Published: November 24, 2014

URL: http://dx.doi.org/10.5539/jgg.v6n4p164

\begin{abstract}
Domestic wastewater is injected into Florida's permeable aquifer system via Class I and Class V wells theoretically to avoid nutrient loading and other contamination that occurs when domestic wastewater is discharged directly to surface waters, resulting in nutrient loading and harmful algal blooms (HABs). The majority of Class I aquifer-injection wells are used to inject secondary-treated effluent from domestic wastewater treatment plants. Class V aquifer-injection wells also include injection of domestic wastewater. As of July 28, 2014, 257 Class I aquifer-injection wells and 14,466 Class V aquifer-injection wells had been permitted in Florida by the Florida Department of Environmental Protection (FDEP), with 34 Class I wells and 10,671 Class V wells located in the Florida Keys, Monroe County and Miami-Dade County, in southeast Florida. The presumption is that the injected wastewater will be contained within the aquifer zone where the injection is permitted and not move into overlying aquifer zones or surface waters. No large-scale monitoring in surface waters is conducted to confirm that the predominantly non-saline domestic wastewater injected into aquifer zones of higher salinities is not discharging to surface waters, such as the near-shore coastal waters in southeast Florida that provide habitat for coral reefs and federally threatened and endangered species, such as sea turtles and manatees. As an example of how such monitoring could be conducted, a case study was initiated in the coastal waters of the Florida Keys to evaluate the hypothesis that: 1) deep-aquifer (Floridan) discharges occur in localized areas of environmental decline and 2) dense benthic macroalgae associated with submarine groundwater discharges (SGD) in those localized areas, exhibit stable nitrogen isotope ratios $\left(\delta^{15} \mathrm{~N}\right)$ indicative of sewage effluent. Sites were selected in near-shore (continental shelf) surface waters in Biscayne Bay (vicinity of Black Point deep-aquifer sewage-effluent injection facility); Card Sound/Barnes Sound; Florida Bay (Everglades National Park); and Florida Keys ocean side (vicinity of $>1000$ primarily shallow-aquifer Class V injection wells). Dissolved helium (He) anomalies in surface waters were used as tracers of groundwater origin. Excesses of ${ }^{4} \mathrm{He}$ indicate deep-aquifer discharges. Greatest ${ }^{4} \mathrm{He}$ excesses were in the Marquesas Keys, where localized coral decline and dense benthic macroalgae occurred, and north Florida Bay, where seagrass dieoff occurred in 1987. Benthic macroalgal samples from sites with dense macroalgal growth and localized coral decline had $\delta^{15} \mathrm{~N}$ ratios indicative of sewage: 1) where sewage effluent disposal was concentrated in aquifer-injection wells, and 2) in the Marquesas Keys, $\sim 40 \mathrm{~km}$ from the nearest shallow-aquifer injection wells, septic tanks, and cess pits. Surfacewater signatures indicative of aquifer-injection zones reconfirm breached (leaky) aquifer confinement and ocean-side Floridan-aquifer discharges for the Keys. Remote sites with deep-aquifer signatures, extensive, dense mats of benthic macroalgae, and $\delta^{15} \mathrm{~N}$ signatures indicative of sewage effluent suggest effluent-laden SGD via karst conduits may be a significant source of localized nutrients supporting these HABs. The locations of our georeferenced and transformed lineaments representing fractures mapped in 1973 in analog format reveal that approximately 100 fractures extend or can be extended through our study area in the coastal waters surrounding the Florida Keys. Of those fractures, 21 are associated with sites with environmental abnormalities (i.e., dense benthic macroalgae with $\delta^{15} \mathrm{~N}$ signatures indicative of sewage effluent; salinity; chlorophyll-a; radon excesses indicative of deep-aquifer discharges; walls of turbid water at deep coral reefs). Six of those fractures are within $1 \mathrm{~km}$ of aquifer-injection wells on Florida's west coast and 15 are within $1 \mathrm{~km}$ of aquifer-injection wells on Florida's east coast. The west coast injection wells include those in the following counties: Charlotte (one Class I
\end{abstract}


well at one facility); Collier (four Class I wells at two facilities); and Lee (three Class I wells at two facilities). East coast injection wells include those in the following counties: Broward (21 Class I wells at nine facilities); Dade (21 Class I wells and 26 Class V wells at 7 facilities and three clusters of Class V wells); Martin (two Class I wells at one facility); Monroe (four clusters of Class V wells at multiple facilities); and Palm Beach (five Class I wells at four facilities). Depths of those Class I and Class V wells range from 668 to $928 \mathrm{~m}$ and 9 to $23 \mathrm{~m}$, respectively. The deeper wells are within geologic formations of the Floridan aquifer system characterized by submarine sinkholes and fractures along southeastern Florida. In addition to sewage effluent, liquid waste from landfills, nuclear power plants and reverse osmosis facilities are injected into wells associated with those fractures that may be transporting those wastes by preferential flow through these fractures to resurface as SGD in near-shore coastal waters surrounding the Florida Keys and coral reefs. These results provide a framework for future research, including groundwater tracer tests in injection wells and studies focusing on the vicinity of those fractures and fracture extensions in coastal waters surrounding the Florida Keys.

Keywords: Floridan aquifer system, fractures, Harmful Algal Blooms (HABs), helium tracers, stable nitrogen isotope, submarine groundwater discharge

\section{Introduction}

\subsection{Background of Aquifer Injection Wells and Submarine Groundwater Discharge}

Ground water traditionally has been overlooked or underestimated in previous studies as a source of anthropogenic nutrient inputs and cause of eutrophication of oceans and estuaries, but Krupa and Gefvert (2005) summarized more recent documentation, as well as methods of identification and measurement, of submarine groundwater discharge (SGD) as a major source causing problems that include anoxia, harmful algal blooms (HABs) and nutrient upwelling in reefs. They reference eutrophication sources such as ground water and recharge areas contaminated by agricultural and urban fertilizers and animal waste, including human sewage injected into shallow wells, septic tanks and cesspools, in addition to other nutrient sources which increase concentrations of nitrogen $(\mathrm{N})$ and phosphorus $(\mathrm{P})$ in SGD. The original geochemical composition of the ground water, the residence time in the aquifer and minerals contacted along the flowpath determine the primary chemical characteristics (aka fingerprint) of SGD. Accurate documentation of SGD is important because these discharges can be unseen hazards and their documentation can be used to assess environmental problems in coastal environments, including crescendo events and concurrent marine algal blooms that degrade water quality, bottom habitats and coral reef ecology, as well as gradual environmental degradation with causes and effects that escape public attention (Krupa \& Gefvert, 2005). An experiment conducted from June 2009 to June 2012, exposing areas of a coral reef near Key Largo to elevated levels of $\mathrm{N}$ and $\mathrm{P}$, resulted in a 3.5-fold increase in coral bleaching and a 2-fold increase in both the prevalence and severity of disease in corals exposed to elevated levels of nutrients compared to corals in control plots. These findings support the conclusions that nutrient loading is one of the strongest drivers of marine habitat degradation and that elevated water temperature is not solely responsible for coral bleaching (Vega Thurber et al., 2014).

Aquifer injections of sewage effluent, stormwater and agricultural/industrial wastewater throughout the United States (US) are regulated by the US Environmental Protection Agency's (USEPA) Underground Injection Control (UIC) rule (40 CFR Part 146). The presumption under that rule is that aquifer-injected fluids do not "migrate" from the point of injection. In Florida, the USEPA's federal regulatory authority over aquifer injections authorized by the UIC Rule is shared with the Florida Department of Environmental Protection (FDEP).

The Marine Protection, Research, and Sanctuaries Act, also known as the Ocean Dumping Act, was adopted by the US Congress in 1972 (Public Law 92-532). This law was enacted because unregulated dumping in ocean waters was endangering human health, welfare, the marine environment, ecological systems, and economic potentialities (PL 92-532, Sec. 2(a)). The purpose of the act was to prevent or strictly limit that dumping of material (PL 92-532, Sec. 2(b)), which includes, but isn't limited to sewage, radioactive materials, biological waste, industrial, municipal, agricultural, and other waste (PL 92-532, Sec. 3(c)). Presumably the intent of injecting domestic wastewater (also known as sewage effluent and municipal wastewater) into Florida's permeable aquifer system was to avoid nutrient loading and other contamination that occurs from discharges of domestic wastewater directly to coastal waters and other surface waters. Ocean outfalls are an example of direct discharges of sewage effluent to coastal waters, via horizontal pipes, with those discharges resulting in HABs. In Florida, domestic wastewater is injected by gravity flow or under pressure, via vertical pipes known as Class I and Class V wells that are permitted by the FDEP. The majority of Class I aquifer-injection wells are used to inject secondary-treated effluent from domestic wastewater treatment plants. According to the Florida Statutes (403.086(e)1, FS), a permit for aquifer-injection of domestic wastewater in Class V wells also can be obtained 
from the FDEP if the design capacity of the facility producing sewage effluent for aquifer injection "is less than 1 million gallons per day (mgd)," which is equivalent to 3785 cubic meters per day, and the injection well is "cased to a minimum depth of 60 feet" $(18 \mathrm{~m})$. Except as provided for backup wells, a permit for aquifer-injection of domestic wastewater in Class V wells also can be obtained from the FDEP if the "design capacity of the facility is equal to or greater than 1 million gallons per day," and each primary injection well is "cased to a minimum depth of 2,000 feet" (403.086(e)2, FS), which is equivalent to $610 \mathrm{~m}$. Class V wells also can be used for aquifer-injection of storm water, surface water, fluids for aquifer storage and recovery (ASR), air conditioning return flow and swimming pool drainage (FDEP, 2014). Although ASR injection wells generally are deep, all ASR wells are permitted as Class V wells (Sidney Bigham, FDEP, pers. comm., October 2014).

Both published data and unpublished information accessible from the regulatory agencies about these aquifer injections are limited. None of the federal, state, regional or local agencies has a comprehensive record of all of the aquifer injections occurring in Florida. The more accessible permitting records, primarily Class I aquifer-injection wells indicate that more than 3.8 million cubic meters per day $(1000 \mathrm{mgd})$ of agricultural/industrial and municipal fluids considered to be wastewater are injected into the aquifer system in Florida. Based on this information, the regional karst Floridan aquifer system underlying Florida is the receiving aquifer for the largest volume of injected contaminated fluids in the US.

The majority of those injection wells are located in the vicinity of south Florida's coastal areas. Despite presumptions of non-migration, both vertical and lateral flow of these injected fluids and aquifer discharges in near-shore (continental shelf) waters have been documented (Paul et al., 2000; Top et al., 2001, respectively), and acknowledged by the USEPA $(1997,2000)$, in areas of south Florida where aquifer injection is most prevalent. Bacchus (2002) provided a synopsis of literature related to (SGD) for the south Florida area. No comprehensive scientific investigation has been conducted to evaluate the influence of those aquifer injections on SGD or associated environmentally sensitive near-shore waters with corals, seagrass beds, sea turtles, or marine mammals.

Spreadsheets compiled by the FDEP provide information regarding each class of aquifer injection wells and the permitted injection volumes for some of the injection wells permitted in Florida by FEDP are available in the Oculus system (http://depedms.dep.state.fl.us/Oculus/servlet/login). The total volume of sewage effluent permitted for discharge via each of these vertical pipes is unknown to the regulatory agencies and the public because that information is not included for any of the wells in the FDEP spreadsheets; FDEP does not have any information about shallow aquifer injections authorized by the county health departments; and some types of Class V injection wells are not permitted by volume (Joe Haberfeld, FDEP, pers. comm., September 2014). Therefore, there is no single, comprehensive database with all of the relevant information for all of the aquifer-injections of sewage effluent and other wastewater in Florida.

Based on information from those spreadsheets, 257 Class I aquifer-injection wells and 14,466 Class V aquifer-injection wells had been permitted in Florida by the FDEP as of July 28, 2014. The Florida Keys, in Monroe County, have 2 permitted Class I wells, both in Key Largo, and 1424 Class V wells. The FDEP has permitted 32 Class I wells and 9,247 Class V wells in adjacent Miami-Dade County. Depths of the casings for the Class I wells in Miami-Dade County range from 552 to $910 \mathrm{~m}$ (1810 to $2985 \mathrm{ft})$ and are $834 \mathrm{~m}(2735 \mathrm{ft})$ deep in the Florida Keys. The injection intervals for Class V wells permitted in Miami-Dade County range from the surface of the well for uncased wells to $30 \mathrm{~m}(0$ to $99 \mathrm{ft})$. The permitting process has not been completed for some of these Class I and Class V wells in Monroe and Miami-Dade Counties.

According to the spreadsheets for Class V wells in Monroe County, the majority of the permitted wells had casing or initial injection depths that ranged from less than a meter to $18 \mathrm{~m}$ ( 1 to $60 \mathrm{ft}$ ), although many of those wells cased to $18 \mathrm{~m}$ were drilled to $27 \mathrm{~m}(90 \mathrm{ft})$. Only 13 of the active Class V wells permitted in the Keys have casing or initial injection depths greater than $18 \mathrm{~m}$ and the casing or initial injection depths for those 13 wells range from 19 to $46 \mathrm{~m}$ (62 to $150 \mathrm{ft}$ ). Approximately 400 of the Class V wells permitted by FDEP in Monroe County did not include information about the depth of the wells. Although the majority of Class V wells in the Florida Keys are considered shallow injection wells, there are exceptions. One example is the injection well for the Key West (Richard Heyman) wastewater treatment plant (facility 93574) on the southern tip of Fleming Key that was permitted as a Class I injection well by a general permit on May 4, 2004. Deep-well injections at that facility began in 2001, the year the initial construction/testing permit was issued (Joe Haberfeld, FDEP, pers. comm., October 2014). A construction permit for these aquifer-injections was issued on April 24, 2007 as a non-ASR Class V injection well. That injection well is included in the FDEP's spreadsheet database for Class V injection wells, rather than Class I injection wells. According to FDEP (Lea Crandall, pers. comm., September 2014) that Class V injection well was "drilled to 3,004 feet" (916 m). 
Class I and comparably deep Class V wells (e.g., at the Key West (Richard Heyman) wastewater treatment plant injection well) in these counties discharge into the highly permeable Boulder Zone of the karst carbonate Floridan aquifer system, while shallow Class $\mathrm{V}$ wells discharge into the permeable karst carbonate surficial aquifers, such as the Biscayne aquifer. The locations of Class I and Class V aquifer-injection wells permitted in Monroe and Dade Counties and coral reefs in southeast Florida, are shown in Figure 1A and B, respectively. In addition to municipal sewage effluent, sewage from cruise ships also is discharged into these aquifer-injection wells in these two counties.

A

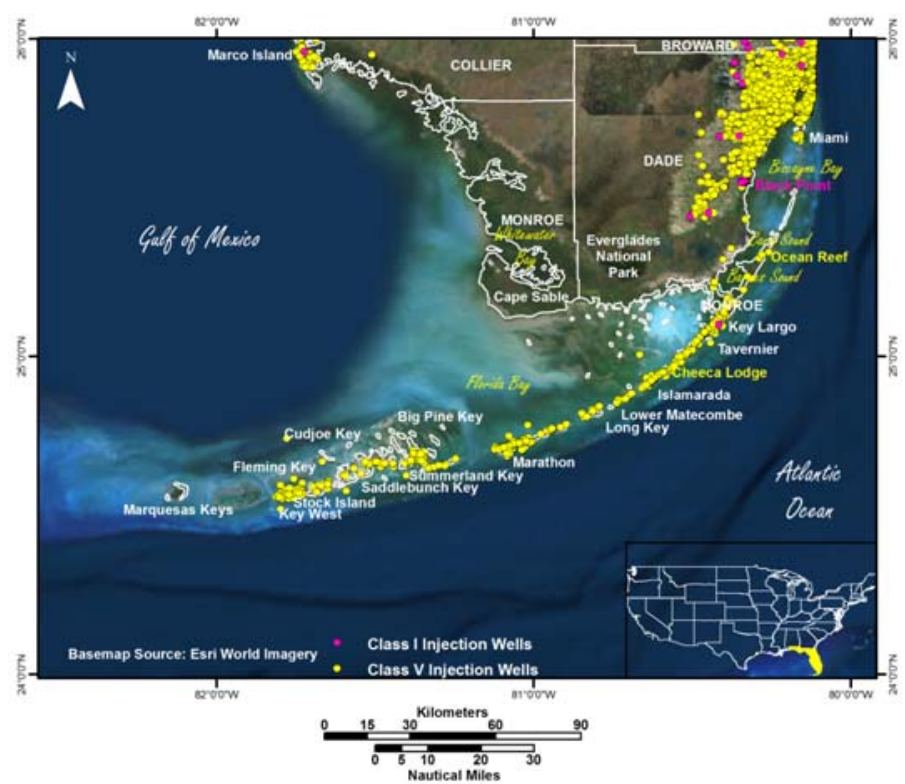

B

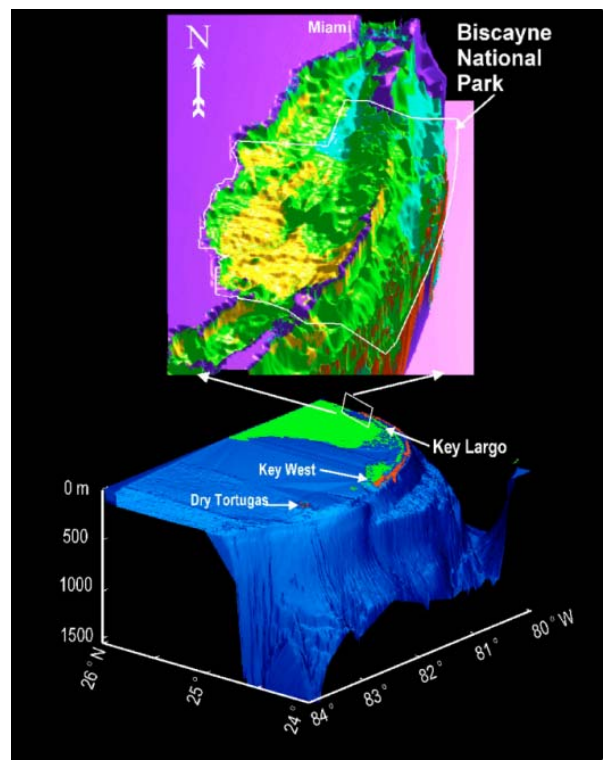

Figure 1. A. Locations of Class I and Class V aquifer-injection wells permitted by the Florida Department of Environmental Regulation in Monroe and Dade Counties and B. proximity of the Florida coral reef tract (in red) along the Atlantic side of the Florida Keys in Monroe County and the shoreline of Miami-Dade County, with the bathymetric features of the submarine Floridan aquifer system in the Atlantic Ocean and Gulf of Mexico of south Florida (from National Oceanographic and Atmospheric Administration, 2001)

Class I aquifer-injection wells are required to be constructed, maintained, and operated so that the injected fluids remain in the injection zone, with unapproved interchange of water between aquifers prohibited. Those wells are required to be tested a minimum of once every five years to evaluate the integrity of the well structure. The purpose of these FDEP regulations is to protect Florida's underground sources of drinking water (USDW), not for compliance with the Clean Water Act (CWA). This distinction is important because the sole regulatory focus of the FDEP and the USEPA has been whether these aquifer injections threaten sources of potable water rather than environmental contamination. The reason for this distinction is that these aquifer injections are permitted under the regulations of the Safe Drinking Water Act (SDWA), which focuses on overlying aquifer zones that may be used to supply drinking water. The presumption of the regulatory and funding agencies is that the injected wastewater will be contained within the aquifer zone where the injection is permitted and not move into overlying aquifer zones or surface waters. Therefore, the concern of the state and federal regulatory agencies is potential leaks from the injection wells and the purpose of any monitoring wells is to detect upward vertical movement of the injected wastewater into overlying aquifer zones, in close proximity to the injection wells.

The inadequacy of the limited monitoring that is required, even for this restricted purpose, was documented in the 2001 study conducted for the USEPA (Starr, Green \& Hull, 2001). The results of that study concluded that the available geochemical data from the limited, land-based monitoring wells in the vicinity of deep-aquifer sewage effluent injection wells in south Florida were insufficient to differentiate between inadequately sealed wells and natural features such as the point source contaminant features. Despite the limited monitoring data, results were sufficient to conclude that, based on mixing trends in water quality parameters, the ammonia contamination in the Floridan aquifer was from effluent.

The monitoring of these aquifer-injection wells also is based on the unsupported presumption that lower 
permeability (also known as confining, semi-confining and breached) zones between the lower and upper Floridan aquifer and surficial aquifers form a continuous barrier between overlying aquifers and surface water (FDEP, 2014). These presumptions ignore both lateral and vertical conduit flow and SGD that can include the injected wastewater and other injected fluids. Figure 2 provides examples of some of these pathways for SGD, illustrated by Krupa and Gefvert (2005, Figures S62 and S63, reprinted with permission) and include SGD adjacent to reefs and as springs along the 2nd reef tract. According to seepage meter and piezometer data from the Biscayne aquifer and Floridan aquifer system in southeast Florida, SGD is most pronounced along the exposed, submarine margin (3rd reef tract) of the aquifer system. This response could be predicted by the cross-section of the Floridan aquifer system published in the US Geological Survey (USGS) Professional Paper 1989 by Meyer and republished by Bacchus (2002, figure 26.1). That figure shows that the aquifer system along southeastern Florida is characterized by submarine sinkholes and other features to depths of approximately 914 $\mathrm{m}(3000 \mathrm{ft})$ and fractures to depths of approximately $1219 \mathrm{~m}(4000 \mathrm{ft})$. Class I and deep Class V aquifer injection wells inject sewage effluent and other fluid wastes within the depths of those fractures, submarine sinkholes and other features.

Figure 1B shows the proximity of the Florida coral reef tract along the Atlantic ocean side of the Florida Keys in Monroe County and the shoreline of Miami-Dade County, and the bathymetric features of the submarine Floridan aquifer system in the Atlantic Ocean and Gulf of Mexico of south Florida. Figure 1B is from the National Oceanographic and Atmospheric Administration (NOAA, 2001) assessment of fisheries resources and habitats in Biscayne National Park. The extent of the submerged platform of the Floridan aquifer system coincides with the margin of the continental shelf. Natural upwelling events occur seasonally along Florida's southeastern coast, depositing water from the depths of the Florida Straits over the deep reefs and the remaining submerged carbonate platform, as shown in Figure 3 (published with permission, courtesy of Ned Smith, Harbor Branch Oceanographic Institute (HBOI)). Paytan et al. (2006) emphasized that despite the widespread distribution of SGD, there is a lack of extensive and quantitative determination of nutrients contributed to coral reef ecosystems. Due to their historic low-nutrient waters, these ecosystems evolved particularly efficient nutrient recycling mechanisms.

A

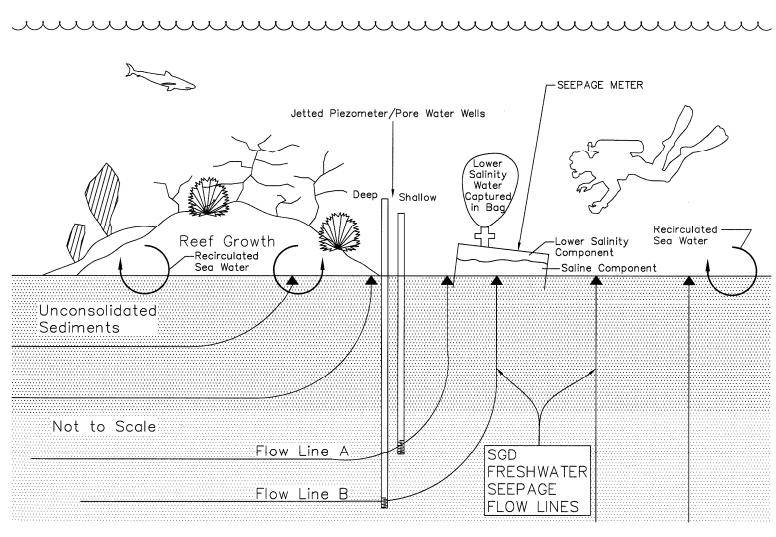

B

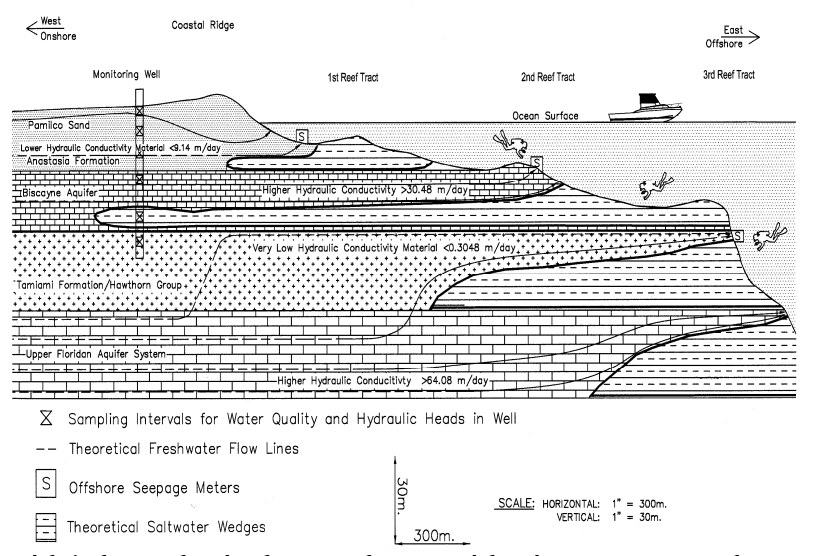

Figure 2. Diagrammatic cross section of southeast Florida's hypothetical near-shore, with piezometers and seepage meters confirming SGD: A. adjacent to reefs and B. as springs along the 2nd reef tract and most pronounced along the exposed margin (3rd reef tract) of the aquifer (from Krupa \& Gefvert, 2005, reproduced with permission)

Preferential SGD that surfaces in areas shown in Figures 2 and 3 can include displaced native, formation ground water, which may range from fresh to hypersaline, depending on the salinity of the formation water in the aquifer injection zone. Preferential SGD also can include injected sewage effluent, stormwater, or other wastewater that enters surface waters as seepage or other discharges through karst conduits (e.g., fractures) and outcrops of lower hydraulic conductivity zones in the Floridan aquifer system at the margin of the continental shelf. No large-scale monitoring in surface waters is conducted to determine the locations and extent of nutrient loading associated with predominantly non-saline domestic wastewater injected into aquifer zones of higher salinities because of the unsupported presumptions that aquifer-injected wastewater and other fluids don't discharge contaminants to 
surface waters, such as the near-shore coastal waters in southeast Florida, where coral reefs and federally threatened and endangered species once thrived. These HABs have been increasing in frequency and intensity in south Florida surface waters, with neurotoxins and expanses of benthic macroalgae becoming serious forms of HAB in south Florida (Barile, 2004; Brand \& Compton, 2007; Brand, Pablo, Compton, Hammerschlag, \& Mash, 2010; Lapointe \& Barile, 2001). Benthic macroalgae are more difficult to detect and track from the surface than planktonic blooms, such as Florida's red-tide events. As a result, HABs involving benthic macroalgae may receive less attention than HABs involving planktonic blooms and consequently the extent and severity of macroalgal blooms may be underreported.

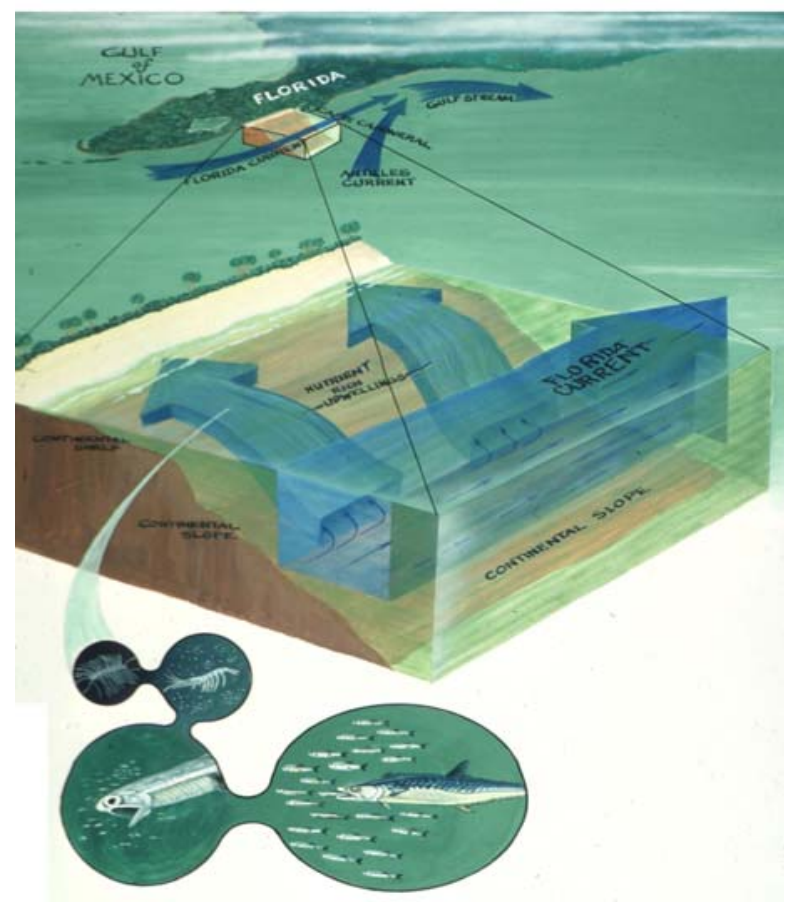

Figure 3. Graphic depiction of natural upwelling events that occur seasonally along Florida's southeastern coast, depositing water from the depths of the Florida Straits over the deep reefs and remaining submerged carbonate

platform (published with permission, courtesy of Ned Smith, Harbor Branch Oceanographic Institute)

\subsection{Antidegradation Requirements of the Clean Water Act}

Regulations of the USEPA under the Clean Water Act (CWA) require each state to "develop and adopt a statewide antidegradation policy and identify the methods for implementing such policy" (40 Code of Federal Regulations \$131.12.). The USEPA (1983) provides the following guidance in interpretation of the antidegradation provision of the CWA (emphasis added):

No activity is allowable under the antidegradation policy which would partially or completely eliminate any existing use whether or not that use is designated in a State's water quality standards. . . Species that are in the water body and which are consistent with the designated use (i.e., not aberrational) must be protected, even if not prevalent in number or importance. Nor can activity be allowed which would render the species unfit for maintaining the use. Water quality should be such that it results in no mortality and no significant growth or reproductive impairment of resident species. ...

Existing uses must be maintained in all parts of the water body segment in question other than in restricted mixing zones.

$\ldots$

If a planned activity will forseeably lower water quality to the extent that it no longer is sufficient to protect and maintain the existing uses in that waterbody, such an activity is inconsistent with EPA's antidegradation policy which requires that existing uses are to be maintained.

The Supreme Court, in its 1994 ruling in PUD No. 1 of Jefferson County, 511 US 700, 719-21, eliminated any 
doubt that the CWA's antidegradation provisions are not restricted to water quality, but also include water quantity and flow. Excerpts of that ruling include the following (emphasis added):

Petitioners also assert more generally that the Clean Water Act is only concerned with water "quality," and does not allow the regulation of water "quantity." This is an artificial distinction. In many cases, water quantity is closely related to water quality; ... First, the Act's definition of pollution as "the man-made or man induced alteration of the chemical, physical, biological, and radiological integrity of water..." 33 U.S.C. § 1362(19). This broad conception of pollution-one which expressly evinces Congress' concern with the physical and biological integrity of water-refutes petitioners' assertion that the Act draws a sharp distinction between the regulation of water "quantity" and water "quality." Moreover, $\S 304$ of the Act expressly recognizes that water "pollution" may result from "changes in the movement, flow, or circulation ..." 33 USC. §1314(f).

To comply with these provisions of the CWA the Florida Legislature has obligated the FDEP to develop a comprehensive program for the prevention, abatement, and control of pollution and to establish protective water quality standards ( $\$ 403.061$, Florida Statutes) and the Florida Statutes (FS) acknowledge that discharges of advanced and secondary waste from sewage disposal facilities must meet the requirements of the antidegradation policy contained in department rules $(\S 403.086(7)(b) 5, F S)$. Additionally, the Florida Statutes specifically address the pollution of the state's waters and other environmental components as follows:

403.021 Legislative declaration; public policy.

(1) The pollution of the air and waters of this state constitutes a menace to public health and welfare; creates public nuisances; is harmful to wildlife and fish and other aquatic life; and impairs domestic, agricultural, industrial, recreational, and other beneficial uses of air and water.

(6) The Legislature finds and declares that control, regulation, and abatement of the activities which are causing or may cause pollution of the air or water resources in the state and which are or may be detrimental to human, animal, aquatic, or plant life, or to property, or unreasonably interfere with the comfortable enjoyment of life or property be increased to ensure conservation of natural resources; to ensure a continued safe environment; to ensure purity of air and water; to ensure domestic water supplies; to ensure protection and preservation of the public health, safety, welfare, and economic well-being; to ensure and provide for recreational and wildlife needs as the population increases and the economy expands; and to ensure a continuing growth of the economy and industrial development.

Despite these federal and state laws, compliance of aquifer injections in Florida with the antidegradation provisions of the CWA cannot be established for several reasons. First, there is no central database with all of the essential information about these aquifer injections, such as the volume of injected fluids and the specific contaminants included in the injected fluids. This lack of information prevents any determination of contaminants that are prohibited from being discharged to surface waters and limits the ability to determine nutrient loading in surface waters. Second, the issuance of these aquifer-injection permits do not require any type of tracer tests to determine where the injected fluids go (i.e., the ultimate surfacewater discharge locations of SGD). Additionally, these aquifer-injection permits do not require any type of monitoring that would evaluate the impacts on any components of the antidegradation provision, such as ensuring that the inevitable changes in water quality will result in no mortality and no significant growth or reproductive impairment of resident species. Both conduit and diffuse discharge (seepage) resulting from these aquifer injections have the capacity to result in significant adverse impacts in near-shore and other surface waters.

\subsection{Study Designs to Address Antidegradation Requirements of the Clean Water Act}

Distribution of plant and animal communities in nature rarely is random. Factors governing distribution of living organisms include favorable surroundings (habitat) and food sources. As an example, early evaluations of near-shore-distribution of organisms in southeast Florida documented what coastal fisherman in Florida had known for years - organisms are attracted to groundwater discharges (Kohout \& Kolipinski, 1967). Although widely recognized, these concepts of non-random community distribution and attraction to SGD have not been applied to study designs evaluating potential adverse environmental impacts of aquifer injections and SGD in Florida, including aquifer injections intended as ASR. For example, Paytan et al. (2006) evaluated SGD as an important source of terrestrial-derived inorganic nitrogen to coral reef ecosystems at various locations worldwide, including off Key Largo in the Florida Keys and emphasized the need to monitor SGD to determine relationships between SGD-associate inputs. Although naturally occurring radium isotope tracers and total inorganic nitrogen (TIN) in submarine ground water from discrete points representing different temporal conditions were averaged in that study, methods for that study restricted those measurements to discrete points along transects extending from the shore toward the reef, without regard to specific areas of dense growth of benthic macroalgae, 
indicative of HABs, or submarine features of preferential groundwater flow. Additionally, transects in that study from the Florida Keys site extended less than $800 \mathrm{~m}(<2625 \mathrm{ft})$ from shore, although that reef tract is located several kilometers offshore. That approach to data collection may provide an approximation of SGD as seepage, but is less likely to document point-source SGD from preferential-flow sites, such as fractures, that may represent significantly larger contributors to terrestrial-derived inorganic nitrogen and other contaminants polluting coral reefs in Florida and other areas.

An analogy to convey the importance of this point in designing environmental studies would be a study design consisting of randomized sample points distributed globally for a census of present-day live coral reefs. This approach to distribution of sample points ignores extensive published data regarding the known locations of present-day live coral reefs. A comparable geologic analogy would be a study design with randomized sample points distributed globally to locate rock samples of historic volcanic origin. A more scientific approach would be to consider data documenting locations where conditions for active volcanoes have occurred and search for rocks of volcanic origin in the vicinity of those locations.

Study designs to determine if existing aquifer injections are complying with antidegradation requirements of the CWA must be multidisciplinary in nature, must begin by recognizing and incorporating the extensive body of hydrogeologic knowledge of karst aquifer systems in general (e.g., preferential flowpaths) and the regional Floridan aquifer system specifically and should include at least two components. The first component is the evaluation of tracers at regular intervals throughout the life of each aquifer-injection well to determine the initial locations of the inevitable SGDs and if those locations change during the course of the aquifer injections. The second component is the collection of samples in areas of potential SGD, based on the extensive body of hydrogeologic knowledge and areas where prolific benthic macrophytes are growing in both coastal and inland surface waters. A prerequisite to obtaining an aquifer-injection permit should be tracer studies to determine where the injected fluids are discharging, while acknowledging that preferential flowpaths in karst aquifers can vary significantly due to groundwater withdrawals, seasonal environmental conditions and other factors (Kincaid, Werner, \& DeHan, 2012).

Because agencies funding coastal research presume aquifer-injected fluids do not resurface in coastal or other surface waters, those agencies have not funded any large-scale, investigations involving environmental implications of injected effluent resurfacing in near-shore waters. Although monitoring aquifer injections with at least the two referenced components and identification of areas of preferential flow should be requirements of aquifer-injections, studies to identify the locations and extent of preferential SGD resulting from aquifer injections could be funded by agencies charged with protecting environmentally sensitive areas such as Florida Bay and Florida's marine sanctuaries, preserves, parks and associated coral reefs.

\section{Study Area and Selected Sites}

\subsection{Study Area}

This case study was conducted in coastal waters surrounding the Florida Keys in southeast Florida, where the earliest record of aquifer injections in FDEP's spreadsheet database was 1957. Only 308 of the more than 1400 Class V aquifer-injection wells recorded in that database included any dates related to permitting or operation of those wells. Environmentally sensitive areas in the study area include Bahia Honda State Park; Big Cypress National Preserve; Biscayne Bay and Card Sound Aquatic Preserves; Biscayne National Park; Coupon Bight Aquatic Preserve; Crocodile Lake National Wildlife Refuge; Dry Tortugas National Park; Everglades National Park; Florida Keys National Marine Sanctuary (FKNMS, incorporating John Pennekamp Coral Reef State Park and the Key Largo and Looe Key National Marine Sanctuaries); Fort Zachary Taylor National Marine Sanctuary; Great White Heron National Wildlife Refuge; Key Largo Hammocks Botanical Site; Key West National Wildlife Refuge; Lignumvitae Aquatic Preserve; Lignumvitae Key State Botanical Site; National Key Deer Refuge; Shell Key Sate Preserve; and San Pedro State Underwater Archeological Site.

The selected area was based on occurrences of bedding planes, fractures, dissolution cavities, and other karst features described in the literature, occurring throughout the submerged carbonate platform (Figure 4, Florida Plateau) forming the seaward extent of the regional Floridan aquifer system. The study area coincides with the south Florida subregion of the Floridan aquifer system where extensive aquifer injections are occurring. 

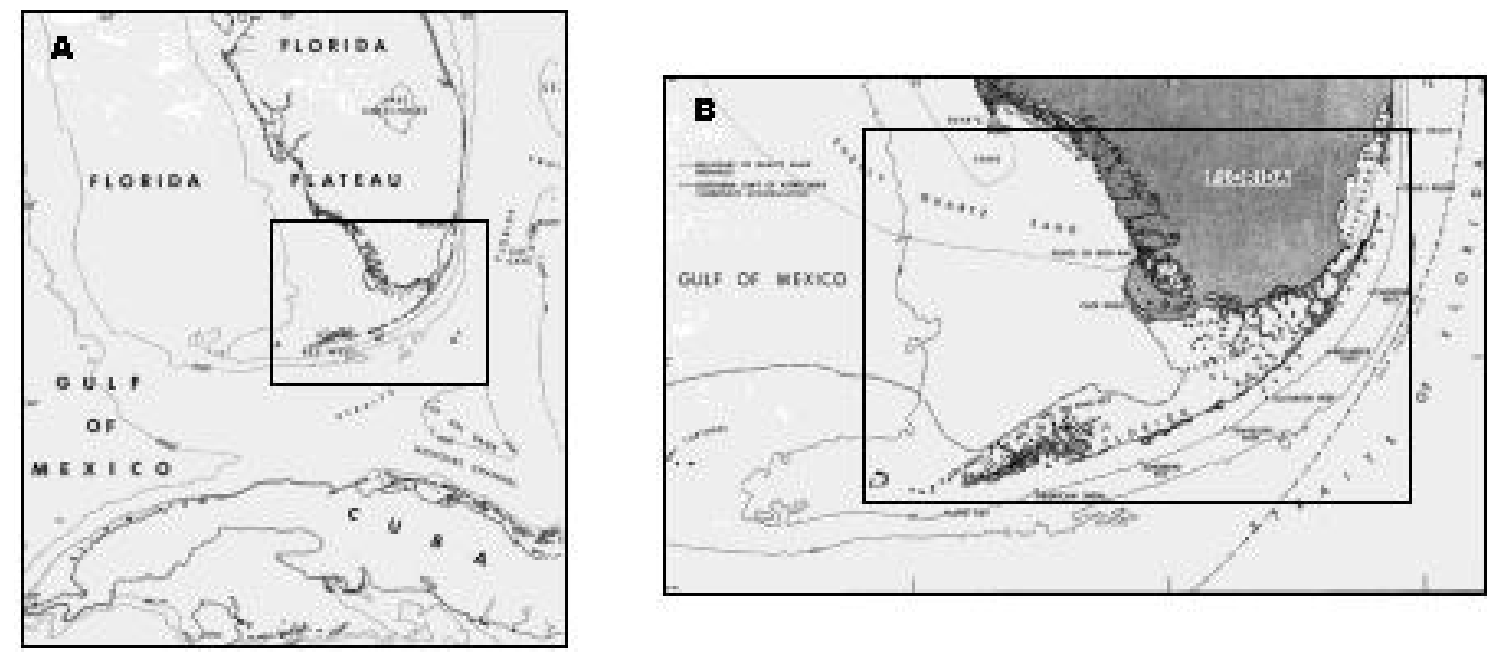

Figure 4. Location of study area on the regional Florida-Bahamas carbonate platform: A. within the extent of the

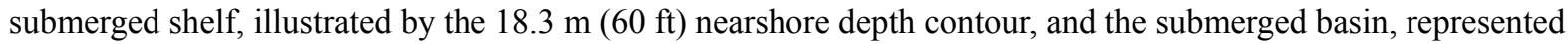
by the $183 \mathrm{~m}(600 \mathrm{ft}$ ) seaward depth contour (from Enos and Perkins, 1977) and B. enlargement of the study area and proximity to the Straits of Florida and the Bahamas

Photographs taken by the senior author exemplifying near-shore submarine features in the study area (e.g., ledges, crevasses and solution holes) that are potential locations for preferential SGD are shown in Figure 5. The photographs in Figures 5A-E were taken on October 6, 2000 and the photograph in Figure 5F was taken on November 6, 2010. Figure 6A-C are photographs taken by the senior author on October 6, 2000 as examples of benthic macroalgae covering portions of the near-shore coral reefs in the study area.

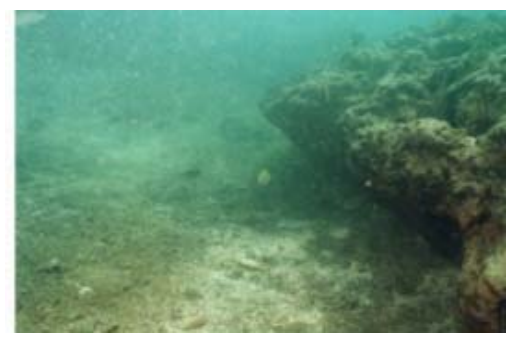

A

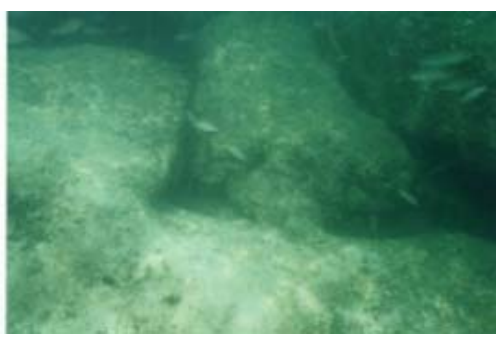

D

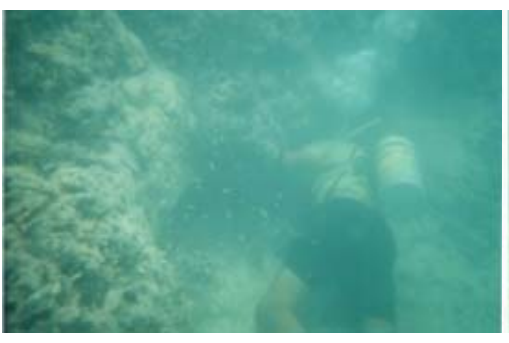

B

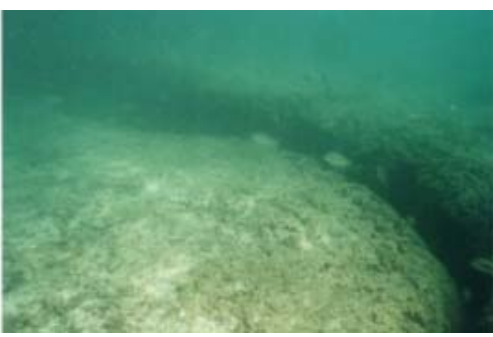

E

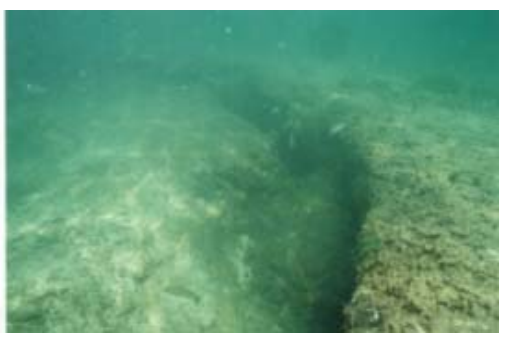

C

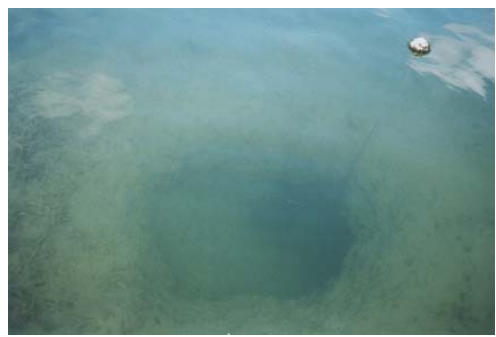

$\mathbf{F}$

Figure 5. Examples of near-shore submarine features in study area as potential locations for preferential submarine groundwater discharge: A. Tavenier north ledge; B. Tavenier south ledge, with scuba diver for scale; C-E. Tavenier south crevasses; and F. Summerland solution hole, with trap float for scale 


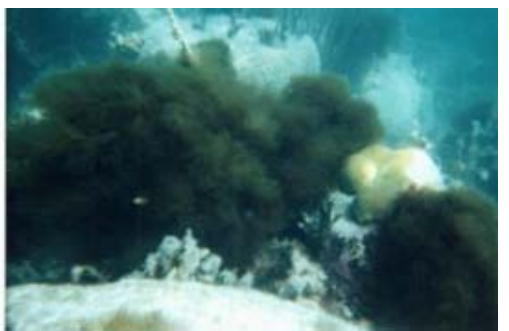

A

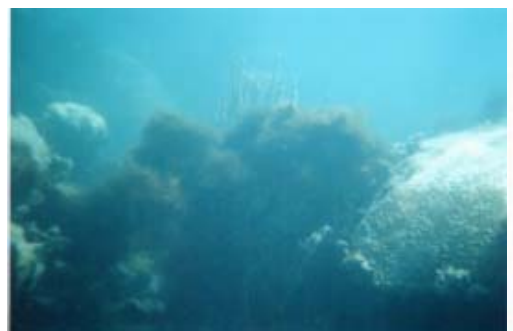

B

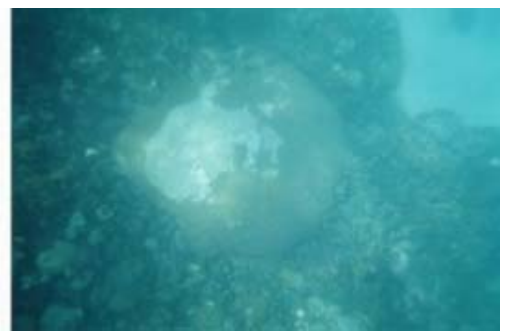

C

Figure 6. A-C. Examples of benthic macroalgae on the near-shore coral reef in the vicinity of Cheeca Lodge on Islamorada

\subsection{Selected Sites}

The study design was based on concentrating sample collections in areas: 1) of potential SGD and 2) where dense benthic macroalgae occurred. The study design also was based on the presumption that when investigating potential environmental impacts of SGD from aquifer injections, more revealing inferences can be made from integrated samples collected at the same time and location than from pooled point data collected under broad spatial and temporal conditions that ignore specific locations of SGD. The objectives of this study were to collect surfacewater and benthic macroalgal samples simultaneously to test the hypotheses that: 1) deep-aquifer (Floridan) discharges occur in localized areas of environmental decline and 2) localized areas of dense benthic macroalgae associated with SGD in those areas exhibit stable nitrogen isotope $\left(\delta^{15} \mathrm{~N}\right)$ ratios indicative of sewage effluent. Additionally, previously mapped fractures in south Florida were evaluated to determine if areas of dense benthic macroalgae were associated with fractures as one pathway for preferential SGD.

Sample sites were selected in the area that extends from Biscayne Bay, in the northeast, to the Marquesas Keys, west of Key West, in the southwest of the Keys (Figure 7A). Sites were selected in near shore (continental shelf) surface waters in Biscayne Bay (vicinity of Black Point deep-aquifer sewage injection facility (aka Miami-Dade South District Wastewater Treatment Plant)); Card Sound/Barnes Sound; Florida Bay (Everglades National Park); and Florida Keys ocean side (vicinity of $>1000$ Class V aquifer-injection wells). Comparative sites also were included from the Gulf of Mexico, adjacent to those waters.

Some of the site locations for the study were selected based on a 1995 hypothesis by Bacchus (2002) that preferential (localized) deep-aquifer discharge occurs in the Marquesas Keys, in north Florida Bay areas where seagrass dieoff was reported in 1987, and in areas of coral decline. Additional site locations for the study were selected based on a subsequent hypothesis that preferential discharge occurs in the Keys in close proximity to shallow aquifer injections of sewage effluent, where coral reefs are declining and where atypical and undesirable macroalgal and cyanobacterial growth are occurring (Bacchus, 2002). The remaining sites included in the study were in areas with previously identified anomalies, including either excessive or negligible benthic macroalgae, or areas of abnormally high chlorophyll-a (chl-a) levels (Figure 7A, Sites A-S). Comparative groundwater tracer sites (Figure 7A, Sites a-i) were selected within the study area to improve interpretation of the tracer results. Site $\mathrm{h}$ was located in the same apparent natural depressional feature as Site F, to provide a comparison of tracer data from the same site for two different seasons and years (April 4, 2002 and August 13, 2001, respectively). Figure 7B is an enlargement of the area with sample sites in the vicinity of south Biscayne Bay and Card Sound. Data from a May 6, $1998 \mathrm{chl}-\mathrm{a}$ transect in the Gulf of Mexico also were included. 

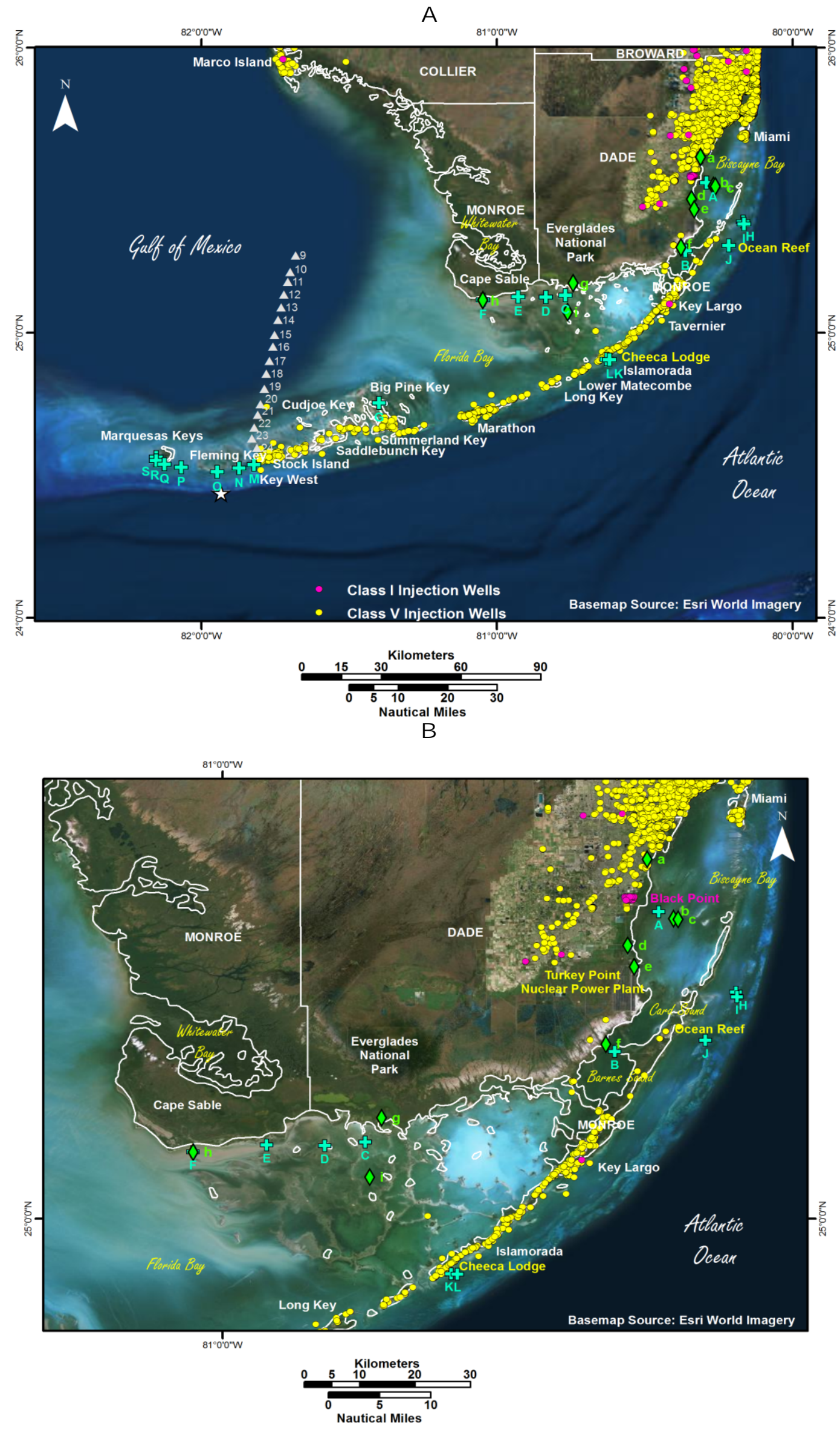


\section{C}

\section{Salinity (ppt)}

$10 \quad 20 \quad 30 \quad 40$
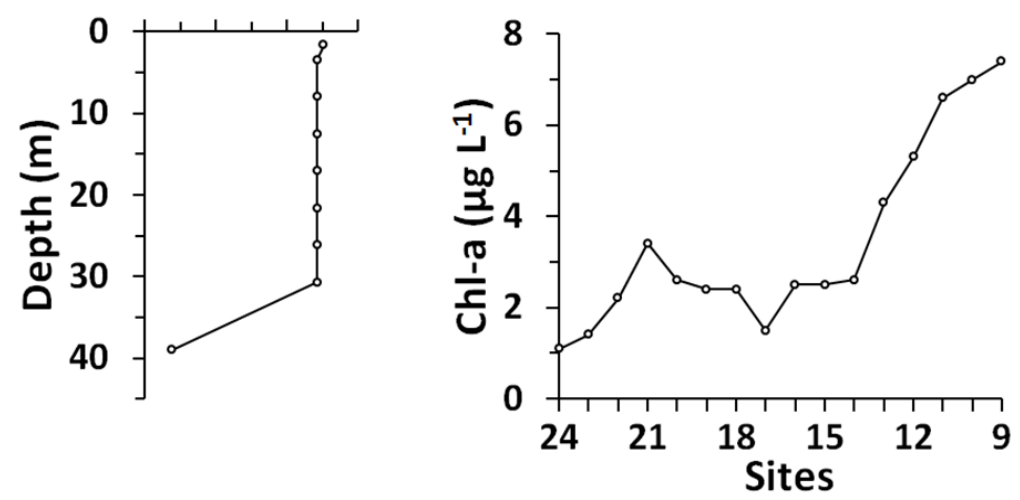

Figure 7. A. Multidisciplinary (aqua crosses A-S) and comparative (green diamonds a-i and gray triangles 9-24) sample sites; selected longterm injection wells at Black Point, Ocean Reef, Cheeca Lodge, Saddlebunch Key,

Stock Island, and Fleming Key benthic wall of turbid water (white star under Site O); and water column salinity and chlorophyll samples (triangles 9-24); B. enlargement of sample sites associated with Biscayne Bay and Turkey Point Nuclear Power Plant (NPP) (symbology as described in Figure 7A); and C. graphs showing the vertical profile of 9 vertical water-column samples of salinity over a Gulf of Mexico submarine depressional feature west of Cape Sable (triangle 9) and the horizontal profile of 16 samples of average chl-a concentrations extending from the same depressional feature, south to Fleming Key, Florida (triangles 9-24)

The study sites were located in Biscayne Bay, the Card Sound/Barnes Sound boundary, Florida Bay, the Gulf of Mexico, and the ocean side of the Keys, from the Upper Keys to the Marquesas Keys, beyond Key West. Six of the selected sites were in sheltered waters extending from Biscayne Bay (northeast study area), to Cape Sable (Florida Bay, northwest study area). These sites included: Black Point, (A); Card Sound Bridge south, in a Barnes Sound dredged depression (B); Rankin Bight (C); Porpoise Point (D); Flamingo (E); and Cape Sable south, in an apparent natural depression $\sim 5.5 \mathrm{~m}(\sim 17 \mathrm{ft})$ deep $(\mathrm{F})$. A seventh site was located in an apparent natural depressional feature in the Gulf of Mexico, north of Big Pine Key $(G)$, where sea turtles frequently are observed (Brian Lapointe, HBOI, pers. comm., June 2001).

The remaining 12 sites were located on the ocean side of the Florida Keys. The five northernmost sites were associated with the Upper Keys: Alina's Reef 1 (H); Alina's Reef 2 (I); Ball Buoy Reef (J); Cheeca Lodge (K); and Cheeca Rocks (L). The final seven sites were located in the Key West National Wildlife Refuge, from Key West to the Marquesas Keys: Key West south (M); Crawfish Key south (N); Ballast Key south (O); Boca Grande Key south (P); Western Harbor south, dead coral head (Q); Mooney Harbor Key, mangrove prop roots (R) and Mooney Harbor channel north (S).

Water depths at the selected sample sites were $\sim 2-4 \mathrm{~m}(6.5-13 \mathrm{ft})$, with one exception. The water depth of the benthic macroalgal bloom at the Mooney Harbor Key mangrove site ranged from $\sim 0.15-0.5 \mathrm{~m}(<2 \mathrm{ft})$. The first nine vertical water column samples from the 1998 Gulf of Mexico data set represent a vertical salinity profile collected from an apparent natural depression, $\sim 40 \mathrm{~m} \mathrm{(} \mathrm{130} \mathrm{ft)} \mathrm{deep} \mathrm{from} \mathrm{water} \mathrm{surface} \mathrm{to} \mathrm{bottom} \mathrm{(Figure} \mathrm{7C,}$ left graph). Water depth surrounding the submarine depressional feature was $\sim 10 \mathrm{~m}(\sim 30 \mathrm{ft})$. Samples 9-24 of that data set represent a horizontal profile of chl-a extending from the submarine depressional feature, south to Fleming Key (Figure 7C, right graph).

\section{Methods}

\subsection{Environmental Samples}

Surfacewater samples were analyzed for helium (He) isotope content to determine the origin and approximate age of the sample. Benthic macroalgal samples were analyzed for stable nitrogen isotope $\left(\delta^{15} \mathrm{~N}\right)$ ratios. Water column samples also were analyzed for chl-acontent. Previously unpublished relevant data collected independently of the study were evaluated in conjunction with data collected during this study for comparative purposes. Collection dates for study and comparative samples were: 3/6/03 for b-e; 4/23/02 for f; 4/4/02 for h; 8/15/01 for G; 8/14/01 for M-S; 8/13/01 for C-F, K, L; 8/12/01 for A, B, H-J; 8/01 for g, i; and 5/6/98 for 1-24. 
Depths for isotopic groundwater tracer samples collected from comparative sites (Table 1) included: land surface (free-flowing) discharge of ground water at the east end of 168th St. southwest, Biscayne Bay shoreline (Site a); $\sim 3 \mathrm{~m}$ and $\sim 20 \mathrm{~m}$ below bottom in Biscayne Bay wells (Sites b and c, respectively); $10 \mathrm{~m}$ below land surface in USGS well G3639 (Site d); and the bottom of the Mowry canal (Site e). Surfacewater samples for isotopic analysis were collected at a depth of $\sim 2-4 \mathrm{~m}$ from the remaining comparative groundwater tracer sites, at Card Sound, Monroe Lake in Florida Bay, Cape Sable southeast, and Whipray Key north (Sites f-i, respectively), and at the study sites. The sole exception was the Mooney Harbor Key study (Site R), where the sample was collected from the mid-depth of the benthic macroalgal bloom $(\sim 0.5 \mathrm{~m})$ adjacent to the mangrove prop roots.

Water samples for He isotope measurements were collected and analyzed as described by Top et al. (2001). The precision of this method $\left(\leq 0.01 \mathrm{TU} ; 1 \mathrm{TU}=1{ }^{3} \mathrm{H} / 1018 \mathrm{1H}\right)$ is an order of magnitude higher than can be obtained with radioactive counting. Because the original groundwater equilibration temperature is not accessible, and the corrections are based on the measured temperature $\left(25-30^{\circ} \mathrm{C}\right)$ of the samples, a small uncertainty may be introduced in these estimates. Saturation anomalies $\Delta^{4} \mathrm{He}$ and $\Delta^{3} \mathrm{He}$ were then calculated for both He isotopes, with respect to the solubility equilibrium values given by Top et al. (1987). Individual samples for analysis of $\delta^{15} \mathrm{~N}$ in benthic macroalgae consisted of pooled algae from three individuals of a single species, for each species present at that site (Site $\mathrm{n}$ ). Analysis of $\delta^{15} \mathrm{~N}$ in benthic macroalgal samples was as described by Barile (2004). Methodology to determine chl-a levels in surfacewater samples was described by Brand (2002).

\subsection{Analog to Digital Conversion of Lineaments Representing Fractures}

The raster layer containing the Florida Department of Transportation (FDOT, 1973) lineaments and its accompanying Landsat mosaic, that were used to generate a digital map of lineaments for selected areas of north Florida by Lines et al. (2012) and Bernardes et al. (2014) were reprocessed and geometrically transformed. Layer reprocessing guaranteed an improved positional fit of features in southern Florida. We took advantage of the common geometry and of the fact that the mylar overlay with the FDOT lineaments matches its source (the analog Landsat mosaic). Corresponding features (punch holes and tick marks), originally used for physical alignment of the analog versions of these documents were, in a similar fashion, used to align their digital representations (i.e., images scanned at $600 \mathrm{dpi}$ ). The digitally aligned mosaic and lineament images then were stacked as a four-band image (red, green and blue bands from the Landsat mosaic, plus a lineaments band) and 195 control points were acquired over the entire State of Florida, as shown in Figure 8. Control point acquisition used analog features found on the Landsat mosaic and on a geometrically correct reference layer (False Color/Near Infrared (432) 1975-2010 base layer from ArcGIS Online). Following control point identification and analysis, a second order polynomial was used for the geometric transformation of the stacked image. Finally, the FDOT lineament map was exported from the image stack.

\subsection{Analog to Digital Conversion of Salinity, Chl-a and Radon Excesses}

Analog to digital conversion was used to prepare salinity and chl-a maps produced by Larry E. Brand, from the University of Miami, Rosenstiel School of Marine and Atmospheric Science for incorporation into our database. Similarly, a radon excesses map authored by Top et al. (2001) was converted to digital format and incorporated into our database. During the conversion of analog maps into digital format, scanned versions of these maps were matched to a geometrically correct reference layer (Imagery Basemap from ArcGIS). The matching procedure involved the collection of control points over the maps by identifying corresponding features on each map and on the reference layer. Acquisition of control points considered the collection of an adequate number of points, as well as the even spatial distribution of points over the region. Selected points were inspected for positional errors and adequately supported the geometric transformation of each map, while matching the reference image. Control point identification and analysis were followed by the geometric transformation of each map by using a second order polynomial. 
Table 1. Results of isotopic tracer and macroalgal analyses

\begin{tabular}{|c|c|c|c|c|c|c|c|}
\hline $\begin{array}{c}\text { Site } \\
\text { location } 1\end{array}$ & $\begin{array}{l}\text { Distance } \\
(\mathrm{km})^{2}\end{array}$ & $\begin{array}{c}\text { Total He } \\
\left(1 \mathrm{E}-8 \mathrm{cc} \mathrm{g}^{-1}\right)^{3}\end{array}$ & $\begin{array}{l}\Delta^{4} \mathrm{He} \\
(\%)^{4}\end{array}$ & $\begin{array}{l}\Delta^{3} \mathrm{He} \\
(\%)^{5}\end{array}$ & $\begin{array}{l}\text { Tritium } \\
\text { (TU) }^{6}\end{array}$ & $\begin{array}{l}{ }^{3} \mathrm{H}^{-3} \mathrm{He} \\
\text { age }(\mathrm{yr})^{7}\end{array}$ & $\begin{array}{c}\delta^{15} \mathrm{~N}_{ \pm} \mathrm{SD} \\
(\% \circ)^{8}\end{array}$ \\
\hline \multicolumn{8}{|c|}{ Comparative samples: } \\
\hline a & $\sim 8 \mathrm{~N}$ & 4.84 & 12.8 & 13.78 & 3.07 & 12.92 & - \\
\hline b & $\sim 8 \mathrm{E}$ & 4.61 & 18.3 & 40.04 & 2.48 & 26.77 & - \\
\hline $\mathrm{c}$ & $\sim 8 \mathrm{E}$ & 4.83 & 27.5 & 72.56 & 1.41 & 44.08 & - \\
\hline d & $\sim 8 \mathrm{~S}$ & 5.04 & 26.0 & 35.70 & 3.22 & 22.10 & - \\
\hline $\mathrm{e}$ & $\sim 8 \mathrm{~S}$ & 5.43 & 43.3 & 39.12 & 5.45 & 16.37 & - \\
\hline $\mathrm{f}$ & $\sim 30 \mathrm{~S}$ & 5.08 & 34.9 & 36.61 & 3.00 & 22.55 & - \\
\hline $\mathrm{g}$ & $\sim 55 \mathrm{SW}$ & 5.31 & 46.2 & 46.85 & 2.10 & 30.38 & - \\
\hline h & $\sim 88 \mathrm{SW}$ & 4.78 & 29.1 & 32.29 & 3.00 & 20.78 & - \\
\hline $\mathrm{i}$ & $\sim 63 \mathrm{SW}$ & 6.48 & 78.3 & 28.74 & 2.10 & 23.59 & - \\
\hline \multicolumn{8}{|c|}{ Multidisciplinary samples: } \\
\hline $\mathrm{C}$ & $\sim 65 \mathrm{SSW}$ & 5.84 & 54.9 & 14.44 & 2.07 & 16.01 & $\ddagger$ \\
\hline $\mathrm{F}$ & $\sim 88 \mathrm{SW}$ & 4.23 & 13.7 & 13.85 & 2.28 & 14.45 & $\ddagger$ \\
\hline G & $\sim 168 \mathrm{SW}$ & 5.15 & 42.5 & 49.21 & 1.63 & 34.84 & $\ddagger$ \\
\hline $\mathbf{J}$ & $\sim 30 \mathrm{SE}$ & - & - & - & - & - & $7.0 \pm 2.6$ \\
\hline $\mathrm{K}$ & $\sim 72$ SSW & 4.98 & 36.5 & 27.80 & 1.08 & 32.57 & 6.04 \\
\hline $\mathrm{L}$ & $\sim 72 \mathrm{SSW}$ & 5.01 & 37.6 & 39.87 & 1.17 & 36.84 & $8.5 \pm 3.5+4$ \\
\hline Q & $\sim 230 \mathrm{SW}$ & 5.54 & 53.4 & 27.71 & 1.19 & 30.93 & $6.3 \pm 0.7$ \\
\hline $\mathrm{R}$ & $\sim 230 \mathrm{SW}$ & 5.43 & 52.0 & 14.79 & 1.13 & 22.77 & $6.5 \pm 0.7$ \\
\hline $\mathrm{S}$ & $\sim 230 \mathrm{SW}$ & 5.20 & 41.3 & 48.23 & 1.10 & 41.03 & $5.7 \pm 0.9^{*}$ \\
\hline
\end{tabular}

${ }^{1}$ Location information for comparative and multidisciplinary sites is as described in "Study area and selected sites" and as shown in Figure 2. "Straight line distance of site from Black Point injection well field. ${ }^{3}$ Total helium (corrected based on neon). ${ }^{4}$ Total helium excess above solubility equilibrium. ${ }^{5} \mathrm{Helium}^{3}$ excess above solubility equilibrium (tritiogenic helium $\left.{ }^{3}\right) .{ }^{6}$ Tritium $\left({ }^{3} \mathrm{H}\right)$ concentration, provided in Tritium Units $\left(1 \mathrm{TU}=1^{3} \mathrm{H} / 10181 \mathrm{H}\right)$. ${ }^{7}$ Tritium-helium age of the sample. ${ }^{8}$ Mean $\delta^{15} \mathrm{~N}$ values for benthic macroalgae \pm standard deviation for the following sample sizes $\mathbf{n}$ (number of species sampled per site), respectively: $5,1,3,14,9,9$. \$Apparent insufficient light penetration for benthic macroalgal growth. $\$$ Combining the 3 samples of the single species at site $L$ with samples from the 3 species at close-proximity site $\mathrm{K}$ resulted in a total of $7.9 \pm 3.5$. $* 0.8$ sample value outlier discarded.

\section{Results}

\subsection{Isotopic Groundwater Tracers}

The results for He isotope analysis of benthic surfacewater and comparative samples, including measured concentrations and percentage excess over solubility equilibrium for both isotopes are summarized in Table 1 . Tritium-helium $^{3}$ age, the apparent time period elapsed since the forming of ground water (during which tritium decays into ${ }^{3} \mathrm{He}$ ) was calculated (Table 1). Although these ages are included in the present analyses, they are a derived parameter. The apparent age is more difficult to interpret when waters of different ages mix, as is the case in this study. The more abundant isotope, ${ }^{4} \mathrm{He}$, is the radioactive decay product of the Uranium and Thorium chain elements. It accumulates in the rocks over geologic periods and has been shown to be a proxy for old ground water (e.g., Clarke \& Kugler, 1969; Clarke et al., 1976). Conversely, ${ }^{3} \mathrm{He}$ is produced in the radioactive decay of tritium $\left({ }^{3} \mathrm{H}\right)$, a byproduct of the atmospheric nuclear tests of nearly five decades ago. Therefore, ${ }^{3} \mathrm{He}$ is a proxy for young $(<50 \mathrm{yr})$ ground water. 


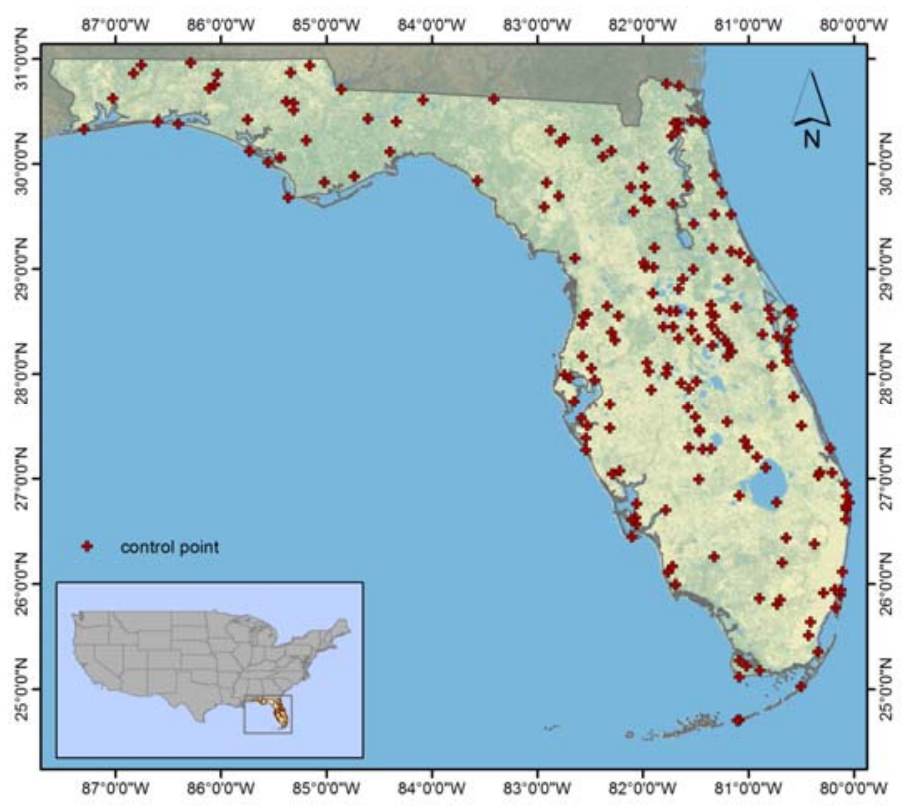

Figure 8. Locations of 195 control points acquired over the entire State of Florida for transformation of Florida Department of Transportation analog lineaments map

All comparative sites, except the free-flowing ground water near the shore of Biscayne Bay $(168 \mathrm{E})$, had ${ }^{3} \mathrm{He}$ magnitudes $\geq 30 \%$. These values are indicative of a large component of water originating from the shallow (Biscayne) aquifer. Tritium concentrations at these sites approximated present day rain values $(\sim 2-3$ TU), with the exception of the $\sim 20 \mathrm{~m}$ deep sample from the well in Biscayne Bay (Site c). The only surfacewater sample collected from a canal (site e) had the largest ${ }^{4} \mathrm{He}$ excess $(43.3 \%)$ of the samples from the vicinity of Biscayne Bay, suggesting the presence of a larger component of deep-aquifer water in that canal. The ${ }^{3} \mathrm{H}$ of the canal sample (5.45 TU), however, is much higher than the rain value, and is inconsistent with a 'zero tritium' component. It is not clear whether the high ${ }^{3} \mathrm{H}$ in the canal is due to a contamination from the nearby Florida Power and Light (FP\&L) Turkey Point Nuclear Power Plant (NPP), or to some other cause. Such contradictory evidence as high $\Delta^{4} \mathrm{He}$ with high ${ }^{3} \mathrm{H}$ (Site e), and low $\Delta^{4} \mathrm{He}$ with low ${ }^{3} \mathrm{H}$ (Site c) probably is indicative of the complex nature of the south Florida groundwater system and interconnections between the deep and shallow aquifer zones. According to the FDEP Class V spreadsheets for Miami-Dade County, a permit for an aquifer-injection well with a casing depth of $13 \mathrm{~m}$ (42 ft) was issued to FP\&L for the Turkey Point NPP on May 1, 1992, approximately 10 years after the construction permit was issued. That was the aquifer-injection well that was operational at the Turkey Point NNP when the samples in our study were collected. According to the FDEP Class I spreadsheets for Miami-Dade County, an additional construction permit for an aquifer-injection well with a casing depth of 910 m (2985 ft) was issued to FP\&L for the Turkey Point NPP on July 31, 2012.

For the apparent natural depressional feature south of Cape Sable, ${ }^{3} \mathrm{H}$ concentrations were similar for the 2001 wet season and 2002 dry season samples (Sites F and h, respectively), while ${ }^{4} \mathrm{He}$ and ${ }^{3} \mathrm{He}$ excesses were lower in 2001 wet season. The limited data set is insufficient to determine if significant seasonal differences occur at a specific site, or whether any differences are the result of nonseasonal, pulsed discharges of ground water.

Samples from all study sites had large ${ }^{4} \mathrm{He}$ excesses (above solubility equilibrium), suggesting an input of deep (Floridan aquifer) ground water (Table 1). For comparison, Top et al. (2001) found the average values for ${ }^{4} \mathrm{He}$ and ${ }^{3} \mathrm{He}$ excesses in Florida Bay to be $15 \%$ and $19 \%$, respectively. Tracer samples for that study were collected approximately monthly during the summer and winter of 1998-1999, primarily in Florida Bay (Larry Brand, pers comm. April 2004). All but one of the study sites (Site F=13.7\%) and one of the comparative sites (Site $\mathrm{a}=12.8 \%$ ) for the study exceeded the Florida Bay average for ${ }^{4} \mathrm{He}$ excess reported by Top et al. (2001). Furthermore, all but three of the study sites (Site $\mathrm{C}=14.4 \%$, Site $\mathrm{F}=13.9 \%$, and $\mathrm{Site} \mathrm{R}=14.8 \%$ ) and one of the comparative site (Site a $=13.8 \%$ ) exceeded the Florida Bay average for ${ }^{3}$ He reported by Top et al. (2001). The significance of those results cannot be determined because they represent single samples collected from separate locations. Data for the summer and winter samples from the Top et al. (2001) study were averaged in an attempt to quantify groundwater input to Florida Bay waters. The purpose of this study was not to quantify input, but to 
identify localized areas of SGD associated with environmental decline, for further investigation.

Samples from Sites i, C, Q, and R, paired by similar location, stand out with exceptionally high ${ }^{4} \mathrm{He}(>50 \%)$ and relatively lower ${ }^{3} \mathrm{He}(<30 \%)$ excesses (Figure 7$)$. The first pair of these samples was collected from sites located $\sim 8 \mathrm{~km}(5 \mathrm{mi})$ apart in Florida Bay, north of Whipray Keys and in Rankin Bight (Sites i and C, respectively). The second pair of samples was collected from sites located $\sim 2.5 \mathrm{~km}(1.5 \mathrm{mi})$ apart in the Marquesas Keys (Sites Q and $\mathrm{R}$, respectively). A third site in the Marquesas Keys (Site $\mathrm{S}$ ) was in closer proximity, $<0.8 \mathrm{~km}(0.5 \mathrm{mi})$ to Site $\mathrm{R}$, but exhibited a notably greater ${ }^{3} \mathrm{He}$ excess $(48.2 \%)$ and lower ${ }^{4} \mathrm{He}$ excess $(41.3 \%)$ than was recorded for the site in closer proximity (Site R). These anomalies illustrate the considerable heterogeneity of the SGD that can occur over relatively small distances within the study area.

The groundwater source for those Florida Bay (Sites i and C) and Marquesas Keys (Sites Q and R) pairs of samples is likely to be the same, and must contain a large component of deep (Floridan) aquifer water of older age to account for the unusually high ${ }^{4} \mathrm{He}$ excesses $(78.3 \%, 54.9 \%$ and $53.4 \%, 52.0 \%$, respectively). This conclusion is confirmed by the highly similar concentrations of tritium in the samples within these two pairs of sites $(2.10 \mathrm{TU}, 2.07 \mathrm{TU}$, and $1.19 \mathrm{TU}, 1.13 \mathrm{TU}$, respectively). The absolute magnitudes of these samples are lower than the present day rain values, an additional indication of a deep aquifer component that has very little or no ${ }^{3} \mathrm{H}$. Dissolved He in a shallow water column $(\sim 1.5 \mathrm{~m})$ comes to equilibrium with the atmosphere in about five days.

In the Florida Bay tracer study (Top et al., 2001), only three sites had ${ }^{4} \mathrm{He}$ excesses indicative of deep (Floridan) aquifer discharges: Cove Point/Barnes Sound (critical habitat for the federally listed crocodile); Buttonwood Sound (north of Rock Harbor/Key Largo); and south of Flamingo. The latter two sites are within the boundaries of Everglades National Park. Actual ${ }^{4} \mathrm{He}$ excesses were not reported for those sites, but were reported to be in the range of $40-310 \%$. Those localized clusters were attributed to "discreet groundwater sources". Those sites were not located on the ocean-side of the Keys, or associated with areas of coral, such as the Keys reefs. Data from the Florida Bay study, showing co-presence of ${ }^{4} \mathrm{He}$ and ${ }^{3} \mathrm{He}$ excesses, suggested that the mingling of Floridan (old) and Biscayne (younger) aquifer waters occurred before discharge of that ground water to Florida Bay (Top et al., 2001). To maintain the anomalies observed in this study, localized inputs of SGD much larger than the $6-10 \mathrm{~cm}$ d- ${ }^{1}$ calculated by Top et al. (2001) over the Florida Bay area must be occurring. A more extensive investigation has not been conducted in this area to determine temporal and spatial trends of deep-aquifer SGD.

The results of these two tracer studies provide additional support for the conclusion drawn from earlier literature that discharge through karst conduits or comparable preferential flow paths is occurring throughout the study area. These conditions are not conducive to the application of standard randomized, haphazard, kriging and grid study design approaches, as have been used for data collection and analysis in agency-funded field studies within the study area.

\subsection{Benthic Macroalgal $\delta^{15} N$ Signatures}

\subsubsection{Marquesas Keys}

The three sites for the study samples in the Marquesas Keys were selected based on the presence of extremely dense stands of benthic macroalgae. One of the three sites (Site Q) also had a previously living coral head that had declined and died shortly before collection of samples for the study (Peter Barile, HBOI, pers. comm., August 2001). As indicated above, results of surfacewater samples from the Marquesas sites with the recently dead coral head (Site Q) and at Mooney Harbor Key (Site R, the shallowest site of the study), were indicative of a large component of deep (Floridan) groundwater discharge. Despite the remoteness of those sites (e.g., $\sim 40 \mathrm{~km}$ from the nearest septic tanks and cess pits), samples of the dense stands of benthic macroalgae from those sites had $\delta^{15} \mathrm{~N}$ ratios $(6.3,6.5,5.7$, Table 1$)$ indicative of human sewage $(>5)$.

The macroalgal and groundwater tracer results from those sites represent the same period of time and space. Therefore, the combination of these results suggests that nutrient loading from the deep (Floridan) aquifer, as localized SGD, may be maintaining the dense beds of benthic macroalgae at those sites. The source of $\mathrm{N}$ (and potentially other contaminants) at those sites may be the result of deep-aquifer injected sewage effluent from the test injections by the City of Key West (Richard Heyman) wastewater treatment plant on Fleming Key (reported as $18 \mathrm{mgd}$ of secondarily treated effluent injected $\sim 7 / 17-21 / 01$; Greg Smith, pers. comm. April 2004), or larger-volume, longterm injections from the Miami-Dade aquifer injection well field (Figure 7).

\subsubsection{Upper Keys Oceanside}

The closely paired sites on the ocean side of the lower Upper Keys also were selected for collection of study samples based on the presence of extremely dense stands of benthic macroalgae and recently declining coral (K 
and $\mathrm{L}$, respectively). Those sites are closely located to the commercial shallow-aquifer injection well at Cheeca Lodge (Figure 7). The $\delta^{15} \mathrm{~N}$ ratios for those two sites also were indicative of human sewage (6.0 and 8.5, respectively, Table 1). Site L was located on Cheeca Rocks, a shallow reef representative of the '1st Reef Tract' designation illustrated in Figure 2.

The paired Site K was dominated by dense, kelp-like clumps of frondose macroalgae Sargassum pteropleuron, exceeding $9 \mathrm{~m}$ in length in the $\sim 4 \mathrm{~m}$-deep water column. This virtual forest of benthic macroalgae was anchored to the carbonate rock substrate by holdfasts, and extended along a narrow linear alignment from the vicinity of the Cheeca Lodge site, toward the shallow coral reefs at Cheeca Rocks. The surrounding carbonate rock substrate was barren, and contained no benthic macroalgae. This species of macroalgae represented the most robust specimens observed by Smithsonian staff responsible for international macroalgal research (Barrett Brooks, Smithsonian Institution, pers. comm., September 2001). Dried samples of the S. pteropleuron collected at this site on September 30, 2000 are included in the US National Herbarium, Smithsonian Institution as US Algal Collection specimen numbers 222938 and 222939. The first collection of this species from Monroe County was on June 4, 1924 and associated with Loggerhead Key, while the first collection from Dade County was on September 11, 1934 from Miami Beach (US Algal Collection. http://collections.mnh.si.edu/search/botany/). Previous observations and samples of other macroalgal species and cyanobacteria such as Schizothrix (primitive bluegreen algae), at the Cheeca Rocks site also were reported to be the most robust specimens observed by the Smithsonian staff. The cyanobacteria were growing in spherical masses in the center of patches of dead coral (Bacchus, 2002).

Conditions like those documented at the Cheeca Rocks site illustrate the importance of considering species composition and abundance for a comprehensive evaluation of potential SGD-related nutrient loading. The limited scope of the study did not encompass evaluating shifts in macroalgal species composition (from typical to atypical species) and abundance as indicators of nutrient loading, or species-specific differences with respect to uptake of available nutrients. Lapointe \& Barile (2001) documented significantly different $\delta^{15} \mathrm{~N}$ ratios for invasive Codium isthmocladum $(7.2 \pm 0.9)$ and Caulerpa spp. $(5.5 \pm 0.9)$ at their deep reef sites (north of the study area) during the dry season. Significant differences in responses to $\mathrm{N}$ and $\mathrm{P}$ enrichment between frondose (leafy) and calcareous forms of macroalgae in Caribbean ecosystems also have been documented (Lapointe et al., 1987). Specifically, both $\mathrm{N}$ and $\mathrm{P}$ increased in frondose algae in response to $\mathrm{N}$ and $\mathrm{P}$ enrichment, while the calcareous algae (Halimeda opuntia) only responded to N enrichment. Sparse growths of Halimeda are typical on unenriched reef sites. Samples of the few sparse H. opuntia growing at the Cheeca Rocks reef site were included in the determination of $\delta^{15} \mathrm{~N}$ ratios for that site. The $\delta^{15} \mathrm{~N}$ ratio for the samples of that species was considerably lower than the ratio for frondose algae species that were extensive and covering the corals at that site when the samples were collected for this study. When the samples of the single benthic macroalgal species at Site L in our study were combined with the samples from the three macroalgal species at the closely paired Site $\mathrm{K}$ the results for the combined samples were 7.9 \pm 3.5 .

The site at Ball Buoy Reef, on the ocean side of the Upper Keys, also was selected for collection of study samples based on dense benthic macroalgae and recently declining coral (Figure 7, Site J). This site is in the vicinity of the Ocean Reef community's shallow-aquifer injection well, one of the oldest in the Keys. The $\delta^{15} \mathrm{~N}$ ratio for macroalgae at that site also was indicative of human sewage (6.0 and 7.0, Table 1). That site also is a shallow reef representative of the "1st Reef Tract" designation illustrated in Figure 2. The Biscayne Bay, Card Sound, Florida Bay, and Gulf of Mexico study sites lacked benthic macroalgae, possibly due to insufficient light penetration in the highly turbid waters at some of those sites. Benthic macroalgae also were absent or too sparse to sample at sites between Key West and the Marquesas Keys and the two Alina Reef sites in the Upper Keys where the water was clear, with adequate light penetration to support benthic macroalgal growth.

\subsection{Chlorophyll-a Levels}

The chl-a levels from Sites A-S were not elevated with respect to surrounding waters. Although chl-a levels can be used as an indicator of planktonic microalgal blooms, they are single point samples, and require repeated sampling in the same location to make inferences about results. Planktonic algae are transported by currents, tides, and wind. Therefore, the repeated appearance over time of planktonic algal blooms in the same location, is indicative of a persistent source of nutrients. Brand (2002) summarized nutrient loading in the study area from surfacewater sources, refuting earlier assertions that major seagrass dieoffs in Florida Bay contributed nutrients to the continuing algal blooms. Those data support the conclusion that surfacewater discharges from the Kissimmee River-Lake Okeechobee-Everglades watershed are a significant source of nutrients capable of maintaining the planktonic algal blooms in the study area, with N-limited conditions in west Florida Bay and P-limited conditions in east Florida Bay, in proximity to the Keys. The determination of limiting conditions of N 
and $\mathrm{P}$ was based on molar ratios of inorganic $\mathrm{N}$ to total $\mathrm{P}$ measured in Florida Bay and nutrient bioassays from 1991 to 1998.

Independent exploratory samples associated with a deep depressional feature of apparent natural origin in the carbonate platform of the Gulf of Mexico were collected May 6, 1998, west of Cape Sable (Larry Brand, pers. comm., April 2004). The total depth of the depressional feature was $\sim 40 \mathrm{~m}(\sim 130 \mathrm{ft})$, while the surrounding depth was approximately $\sim 10 \mathrm{~m}(\sim 30 \mathrm{ft})$. Those point samples were similar temporally, but varied spatially in depth and distance from the depressional feature. Results of water column samples collected along a vertical transect associated with this depressional feature revealed significantly lower-salinity SGD (Figure 7, Site 9). Salinity was measured with a YSI meter. Elevated concentrations of chl-a $\left(7 \mu \mathrm{g} \mathrm{L}^{-1}\right)$ also were associated with this deep depressional feature. The prevailing direction of surfacewater flow in that area is from north to south.

Levels of chl-a were not elevated north of the deep hole when those samples were collected, based on South Florida Water Management District data files. That site also was the initiation point of a horizontal transect of surfacewater samples on that date (Figure 7A, Sites 9-24). Elevated chl-a ( $>3 \mu \mathrm{g} \mathrm{L}{ }^{-1}$ ) was recorded at a second location along the horizontal transect, near the southern terminus of that transect at Site 21$), \sim 13 \mathrm{~km}(8 \mathrm{mi})$ north of the Key West (Richard Heyman) wastewater treatment plant on the south end of Fleming Key (Figure 7A). The FDEP database also includes a Class V injection well located $2 \mathrm{~km}(1 \mathrm{mi})$ southeast of Site 20 and $4.5 \mathrm{~km}(3$ mi) northeast of Site 21, that was constructed for the Truman Annex Sewage Treatment Plant on Key West but (http://ca.dep.state.fl.us/mapdirect/?focus=uic). No date was provided for the construction of that Class V injection well. Considering that Site 20 is north of Site 21 and that the flow of coastal waters in that area was reported as north to south, that well may represent another source or pathway for focused SGD of injected sewage effluent and may be responsible for the increased levels of chl-a at Site 21 (Figure 7A and 7C). Concentrations of chl-a for the remaining samples along the southern terminus, from the shoreward peak decreased toward shore. Due to the natural variability of chl-a in those waters, however, the sample scale was too gross for interpretation.

Samples from the vertical and horizontal transects were not analyzed for nutrient concentrations, although elevated chl-a concentrations suggest elevated nutrients. Deep-aquifer injections of sewage effluent had not been initiated on Fleming Key at the time of that Gulf of Mexico transect. The elevated chl-a near the southern terminus, however, also is located $\sim 13 \mathrm{~km}$ north of Stock Island. Shallow aquifer-injections of sewage effluent had occurred in $\sim 14$ wells on this $\sim 1.5 \mathrm{~km}(\sim 1 \mathrm{mi})$ wide land mass, at a cased depth of $\sim 20 \mathrm{~m}(\sim 60 \mathrm{ft})$, for approximately 20 years, although records are discarded after five years. More extensive sampling in the vicinity of the depressional feature and the transect in proximity to the Fleming Key and Stock Island injection wells may determine if elevated chl-a is occurring in association with localized nutrient-laden SGD from these injection wells.

Water column nutrient concentrations were not evaluated in the chl-a transects or other water samples in this study, but may be presumed to be the cause of the elevated chl-a levels observed. Advanced wastewater treatment (AWT) has been proposed for some of the aquifer-injection facilities to reduce nutrient levels in wastewater. Levels of $\mathrm{P}$ and $\mathrm{N}$ in surfacewater discharges of sewage effluent in Florida, following AWT and "polishing" by man-made wetlands, have been reported to be $1.88 \mathrm{mg} \mathrm{L}^{-1}$ and $6.16 \mathrm{mg} \mathrm{L}^{-1}$, respectively (FDEP, unpublished data). These AWT discharge levels are $>2$ orders of magnitude greater than the "adverse effects" levels of $\mathrm{P}$ and $\mathrm{N}$ for corals. The coral reef nutrient threshold model (summarized by Bacchus, 2002) demonstrates that nutrient concentrations as low as $0.006 \mathrm{mg} \mathrm{L}^{-1}$ of dissolved inorganic $\mathrm{P}$ and $0.014 \mathrm{mg} \mathrm{L}^{-1}$ of dissolved inorganic $\mathrm{N}$ had adverse effects on coral reefs, while similar thresholds for soluble reactive $\mathrm{P}(0.009$ to $\left.0.189 \mathrm{mg} \mathrm{L}^{-1}\right)$ and dissolved inorganic $\mathrm{N}\left(0.01 \mathrm{mg} \mathrm{L}^{-1}\right)$ were reported for macroalgal overgrowth of coral and seagrass habitats over a broad geographic range. Macroalgal growth was maximal and exponential at very low levels of dissolved inorganic $\mathrm{N}\left(0.007\right.$ to $\left.0.014 \mathrm{mg} \mathrm{L}^{-1}\right)$. Therefore, it is important to note that significant nutrient loading of $\mathrm{N}$ and $\mathrm{P}$ can occur even if aquifer-injected AWT resurfaces as SGD.

\subsection{Salinity Stratification}

Salinity data from the vertical transect over the Gulf of Mexico depressional feature (Figure 7C, triangle 9) illustrate the abnormal (inverted) stratification that can result from a large volume of localized, nonsaline SGD in coastal areas. Stratification of lower density water at depth is unstable and will mix with overlying waters; however, any contaminants associated with low-salinity SGD from preferential (localized) flowpaths would be concentrated in close proximity to the point of discharge (e.g., the $\sim 10 \mathrm{~m}$ thick layer along the bottom). Therefore, sampling and monitoring regimes for contaminants (including anthropogenic $\mathrm{N}$ and $\mathrm{P}$ ) that involve collection of water samples at or near the surface may document low levels or the absence of contaminants, 
while localized benthic areas are experiencing high contaminant levels from SGD.

Larger scale stratification also had been observed $\sim 100 \mathrm{~km}$ south of that site, in the vicinity of the Marquesas Keys (Figure 7A, white star). That stratification was described in a February 10, 1994 letter from local fisheries researcher assistant Don DeMaria to the Chairman of the Florida Keys National Marine Sanctuary. The stratification was described as a layer of cold, dirty water $\sim 9-12 \mathrm{~m} \mathrm{(} \sim 30-40 \mathrm{ft})$ thick, moving along the bottom at the outer edge of a reef. The total depth at that site was approximately $30 \mathrm{~m}(100 \mathrm{ft})$, and the thick layer of turbid water reportedly was "pushing" the fish into deep water as the mass of turbid water moved offshore. An unusual and unidentified purple-colored algae also was observed covering the bottom and much of the reef from the vicinity of that area to a few km east of the "wall" of turbid water (Don DeMaria, pers. comm., October 2000). Deeper masses of water that are colder than overlying coastal waters are more stable than the stratification associated with the vertical transect described above.

\subsection{Fractures}

Locations in south Florida of the transformed analog lineaments mapped by the Remote Sensing Section of FDOT (1973), representing fractures throughout the state, are shown in Figure 9 as red diagonal lines. The submarine extensions of those fractures in south Florida are shown as orange dashed lines. Approximately 100 fractures extend or can be extended through our study area in the coastal waters surrounding the Florida Keys. Of those fractures, 21 are associated with sites with environmental abnormalities (i.e., dense benthic macroalgae with $\delta^{15} \mathrm{~N}$ signatures indicative of sewage effluent; salinity; chlorophyll-a; radon excesses indicative of deep-aquifer discharges; walls of turbid water at deep coral reefs). Six of those fractures are within $1 \mathrm{~km}(0.6 \mathrm{mi})$ of aquifer-injection wells on Florida's west coast and 15 are within $1 \mathrm{~km}$ of aquifer-injection wells on Florida's east coast, according to information from the FDEP Class I and Class V database. The west coast injection wells include those in the following counties: Charlotte (one Class I well at one facility); Collier (four Class I wells at two facilities); and Lee (three Class I wells at two facilities). East coast injection wells include those in the following counties: Broward (21 Class I wells at nine facilities); Dade (21 Class I wells and 26 Class V wells at 7 facilities and three clusters of Class V wells); Martin (two Class I wells at one facility); Monroe (four clusters of Class V wells at multiple facilities); and Palm Beach (five Class I wells at four facilities). Depths of those Class I and Class V wells range from 668 to $928 \mathrm{~m}$ and 9 to $23 \mathrm{~m}$, respectively. The deeper wells are within geologic formations of the Floridan aquifer system characterized by submarine sinkholes and fractures along southeastern Florida.

Table 2 summarizes those facilities and injection wells by county. Table 2 also includes the dates that FDEP permitted operational injections and the casing depths for the Class I injection wells. It is important to note that test injections can begin after FDEP construction permits are issued for the injection wells, which may occur from one to three years before the dates of the operational permits included in Table 2. Asterisks in Table 2 indicate which injection wells and sites are associated with intersections of fractures where vertical groundwater flow may be greatest. Depths of those Class I and Class V wells range from 668 to $928 \mathrm{~m}$ and 9 to $23 \mathrm{~m}$, respectively. The deeper wells are within geologic formations of the Floridan aquifer system characterized by submarine sinkholes and fractures along southeastern Florida. In addition to sewage effluent, liquid waste from landfills, nuclear power plants and reverse osmosis facilities are injected into wells associated with those fractures that may be transporting those wastes by preferential flow through these fractures to resurface as SGD in near-shore coastal waters surrounding the Florida Keys and coral reefs.

The linear alignment of the dense, atypical kelp-like clumps of frondose macroalgae S. pteropleuron. that exceeded $9 \mathrm{~m}$ in length, anchored to the bottom along that linear feature, in water only $\sim 4 \mathrm{~m}$ deep, is strong evidence for localized, nutrient-laden SGD from fractures in the vicinity of Cheeca Lodge and Site K that is comparable to the focused discharge of sewage effluent from open-ocean outfall pipes. Two factors provide support for the conclusion that a fracture in this area is providing a preferential pathway for injected sewage effluent discharging to near-shore surface waters. The first is the barren bottom surrounding the area with the linear feature. The second is the dense growth of benthic macroalgae oriented linearly through the otherwise barren bottom. Considering these observed local conditions and alternative sources of nutrients (e.g,, injected sewage effluent, surfacewater runoff, surfacewater discharges from canals) capable of producing such dense and robust growth of this species of benthic macroalgae, we conclude that injected sewage effluent as focused SGD along a fracture is the probable source of nutrient contamination resulting in this algal growth.

Table 2. Injection wells within $1 \mathrm{~km}$ of fractures mapped by the state remote sensing department (FDOT, 1973) that are associated with sites exhibiting environmental abnormalities in the Florida Keys study area 


\begin{tabular}{|c|c|c|c|c|c|c|}
\hline County & Facility & $\begin{array}{l}\text { Injection } \\
\text { Date }\end{array}$ & $\begin{array}{l}\text { \#/Class } \\
\text { of Wells }\end{array}$ & $\begin{array}{l}\text { Injection } \\
\text { Depth }(\mathrm{m})\end{array}$ & Site(s) & $\begin{array}{l}\text { Dist/Dir. } \\
\text { to Site }(\mathrm{km})\end{array}$ \\
\hline \multirow[t]{9}{*}{ Broward $^{1}$} & Broward Co. NDist. & $3 / 30 / 90-4 / 26 / 01$ & $8 / \mathbf{I} \uparrow$ & 820 & $\begin{array}{c}\mathrm{F}, \mathrm{h}^{*} \\
\mathrm{G} \\
\text { salinity } \mathrm{L}^{*} \\
\text { salinity } \mathrm{H}^{*}\end{array}$ & $\begin{array}{l}\sim 155 \mathrm{SW} \\
\sim 210 \mathrm{SW} \\
\sim 140 \mathrm{SW} \\
\sim 166 \mathrm{SW}\end{array}$ \\
\hline & Cooper (ity WTP & $6 / 30 /() 1$ & 1/I & 907 & radonł & $\sim 117 \mathrm{SSW}$ \\
\hline & Coral Spr. Imp. Dist. & $6 / 1 / 86,4 / 1 / 90$ & $2 / 1$ & 884,916 & radon: & $\sim 138 \mathrm{SW}$ \\
\hline & Deerfield Bch. W WTP & $2 / 4 / 09$ & $1 / \mathrm{I}$ & 920 & $\begin{array}{c}\mathrm{F}_{\mathrm{G}} \mathrm{h}^{*} \\
\mathrm{G} \\
\mathrm{C} \\
\text { salinity } \mathrm{L}^{*} \\
\text { salinity } \mathrm{H}^{*}\end{array}$ & $\begin{array}{l}\sim 163 \mathrm{SW} \\
\sim 216 \mathrm{SW} \\
\sim 105 \mathrm{SW} \\
\sim 147 \mathrm{SW} \\
\sim 173 \mathrm{SW}\end{array}$ \\
\hline & Miramar WTP/RO & $7 / 14 / 95$ & $2 / I$ & 928,943 & radont & $\sim 94$ SSW \\
\hline & Miramar WWTP & $6 / 1 / 97,6 / 20 / 97$ & $2 / \mathrm{I}$ & 899 & salinity $\mathrm{H}^{*}$ & $\sim 116 \mathrm{SW}$ \\
\hline & Pembroke Pines WWTP & $6 / 1 / 87,4 / 1 / 94$ & $2 / \mathbf{I}$ & 899,906 & Salinity $\mathrm{H}^{*}$ & $\sim 116 \mathrm{SW}$ \\
\hline & Plantation Cent. Dist. WTP & $6 / 1 / 91$ & 1/I & 847 & $\underset{9}{\mathrm{~F}, \mathrm{~h}}$ & $\begin{array}{l}\sim 137 \mathrm{SW} \\
\sim 192 \mathrm{SW} \\
\sim 171 \mathrm{SW}\end{array}$ \\
\hline & Plantation Reg.WWTP & $9 / 30 / 87,6 / 1 / 92$ & $2 / \mathbf{I}$ & 897,897 & $9 *$ & $\sim 174 \mathrm{SW}$ \\
\hline Charlotte? & Gasparilla Is. WTP & $12 / 1 / 01$ & $1 / I$ & 453 & G & $\sim 250 \mathrm{SSE}$ \\
\hline \multirow[t]{2}{*}{ Collier } & Marco Is. WWTP: & $1 / 1 / 92,11 / 1 / 08$ & $2 / \mathrm{I}$ & 804,805 & Q & $\sim 163 \mathrm{SW}$ \\
\hline & NCCWRF & $6 / 1 / 04, / 1 / 05$ & $2 / \mathbf{I}$ & 785,787 & $\mathrm{O}$ & $\sim 195 \mathrm{SSW}$ \\
\hline \multirow{7}{*}{ Dade $^{4}$} & Black Point/M-D S WWTP & $1 / 14 / 83-11 / 30 / 94$ & $17 / \mathbf{I}$ & $729-815$ & chl-a* & $\sim 175 \mathrm{SE}$ \\
\hline & Hialeah W\&S Dept. & $8 / 13 / 13$ & $2 / \mathbf{I}$ & 907 & salinity $\mathrm{H}^{*}$ & $\sim 107 \mathrm{SW}$ \\
\hline & J. Robcrt Dean & $7 / 15 / 09$ & 1/I & 815 & $\mathrm{~J}$ & $-33 \mathrm{SE}$ \\
\hline & Old S. Dade Landfill & $10 / 3 / 07$ & $5 / \mathrm{V}$ & 23 & $\mathrm{H}, \mathrm{I}$ & $-24 \mathrm{SE}$ \\
\hline & Princetonian MH Park* & $11 / 6 / 93$ & $20 / \mathrm{V}$ & 9 & A & $\sim 11 \mathrm{SE}$ \\
\hline & Turkey Point NPP/FPL & $5 / 1 / 92$ & $1 / \mathrm{V}$ & 13 & $\begin{array}{l}\text { B } \\
\text { e }\end{array}$ & $\underset{\sim 0}{\sim 27 \mathrm{SSE}}$ \\
\hline & $\begin{array}{l}\text { Waste Mgmt M. Landfill } \\
\text { mulliple } \\
\text { multiple } \\
\text { multiple }\end{array}$ & $5 / 8 / 14$ & $\begin{array}{c}1 / \mathbf{I} \\
\text { many/V } \\
\text { many/V } \\
\text { many/V }\end{array}$ & 847 & $\begin{array}{l}\text { radont } \\
\text { a } \\
\text { b,c } \\
\text { radont }\end{array}$ & $\begin{array}{l}\sim 96 \mathrm{SSW} \\
\sim 0-12 \mathrm{SE} \\
\sim 9-16 \mathrm{SE} \\
\sim 58-105 \mathrm{SE}\end{array}$ \\
\hline \multirow[t]{5}{*}{ Lee' } & Cape Coral SW WTP\& WRF & $8 / 17 / 09$ & $2 / \mathrm{I}$ & 900 & chl-a* & 221 SSE \\
\hline & Estero (multiple) & $9 / 25 / 77$ & many/N & & $\star$ & $\sim 220 \mathrm{~S}$ \\
\hline & Ft. Mycrs Bch. WWTP/STP & $1 / 1 / 98$ & $1 / \mathbf{I}$ & 722 & $\begin{array}{l}\text { salinity } L^{*} \\
\text { salinity } H^{*} \\
\text { chl-a* }\end{array}$ & $\begin{array}{l}\sim 171 \mathrm{SE} \\
\sim 195 \mathrm{SE} \\
\sim 207 \mathrm{SE}\end{array}$ \\
\hline & Lehigh Acres WRF* & $1 / 1 / 09$ & $1 / 1$ & 722 & salinity $\mathrm{H}^{*}$ & $\sim 161 \mathrm{SE}$ \\
\hline & Pinewoods WTP/Gulf UC & $6 / 1 / 90$ & $1 / /$ & 788 & 0 & $\sim 215 \mathrm{SW}$ \\
\hline Martin ${ }^{\circ}$ & Tropical Farms & $5 / 1 / 07$ & $2 / \mathrm{I}$ & 668,765 & $\mathrm{R}, \mathrm{S}$ & $\sim .340 \mathrm{SW}$ \\
\hline \multirow[t]{3}{*}{ Monroc } & multiple & & many/V & & $\mathrm{K}, \mathrm{L}$ & $-1-2 \mathrm{SE}$ \\
\hline & multiple & & many/ $/ \mathbf{V}$ & & $\mathrm{i}^{*}$ & $\sim 22 \mathrm{NW}$ \\
\hline & $\begin{array}{l}\text { multiple } \\
\text { multiple }\end{array}$ & & $\begin{array}{l}\operatorname{many} / \mathbf{N} \\
\operatorname{many} / \mathbf{V}\end{array}$ & & $\begin{array}{l}\mathrm{G} \\
\mathrm{g}^{*}\end{array}$ & $\begin{array}{l}\sim 8 \mathrm{NW} \\
\sim 30 \mathrm{NW}\end{array}$ \\
\hline \multirow[t]{4}{*}{ Padm Beach' } & PBCO S Rey. WRF & $12 / 1 / 91$ & $2 / \mathbf{I}$ & 806,811 & E & $\begin{array}{l}\sim 169 \text { SW } \\
\sim 202 \text { SW }\end{array}$ \\
\hline & PBCWTP/I ake Reg. WTP & $6 / 1 / 08$ & 1/I & 899 & R, S & $\begin{array}{l}\sim 282 \mathrm{SW} \\
\sim 190 \mathrm{SW}\end{array}$ \\
\hline & Western Reg. NWWTP & $4 / 1 / 90$ & 1/I & 808 & $15^{*}$ & $\sim 228 \mathrm{SW}$ \\
\hline & Western Reg. WWTP: & $6 / 14 / 91$ & 1/I & 869 & $\begin{array}{l}\mathrm{R}, \mathrm{S} \\
9^{*}\end{array}$ & $\begin{array}{l}\sim 279 \mathrm{SW} \\
\sim 190 \mathrm{SW}\end{array}$ \\
\hline
\end{tabular}

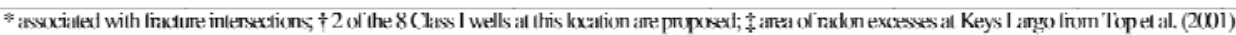
salinity L = low salinity; salinity II = high salinity

${ }^{1}$ Broward Co. North District-2401 N. Powerline Rd, Pompano Beach, FL (2 wells are proposed)

CoxperCily Walter Treatment Plint - 11791 SW 49' S.., Coxper Cily, FT .

Coral Springs Iriprwerment Distrid 10300 NW I I Minur, Coral Spring F

Deerfield Beach West WTP-290 Goolsby Blvd., Deerfield Beach, HL

Miramar Water Treatment Plant/Reverse Osmosis SW $41^{*} \& 136^{\mathrm{t}}$ Ave, Miramar, F

Miramar WasteWater Treatment Plant Pembroke Rd., Miramar, F

Pembroke P'ines WasteWater Treatment Plant - 13995 Pembroke Rd., Miramar FL

Plantation Central District Water Treatment Plant - 700 NW $91^{4}$ Ave,, Plantation, F

Plantation Regional WasteWater Treatment Plant - $6500 \mathrm{NW}$ । I ${ }^{\mathrm{t}}$ Place, Plantation, F

${ }_{3}^{2}$ Gasparilla Island Water Treatment Plant - Linwood Rd. (Lot 12 Lemon Bay Groves), Gaspanilla Island, F L

Marco Iland WasteWater Treatment Plant - 807 Elkham Circle, Maroo Kland, FL (also cluster of Class V wells)

North Collier County Water Reckmation Facility - 10500 Goodlette Rd, Naples, FL

Black PointMiami-Dade S. District WasteWater Treatment PlantDIW-Silver Palm Dr. \& SW 87 Ave.,Miami,FL $~ \sim 2$ km between fracture to H.I \& fracture tob,c)

Hialeah Water \& Sewer Dept. - 501 Palm Ave Hialeah. FL (repoted as completed in 3/25/10 \& 4/11/10)

Old South Dade Landfill - Homestead. $\mathrm{FL}$. Averd

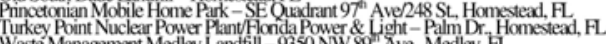

Cape Coral SW Water Treatment PlantWater Reclamation Facility-3310 SW $20^{\circ}$ Ave, Cape Coral, FL (1 well is proposed)

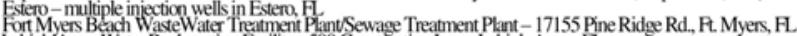

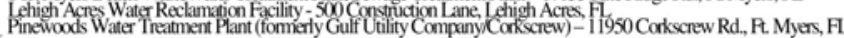

${ }_{7}^{6}$ Tropical Fams -8595 Kansas Blvd., Stuart, FL

Palm Beach County South Regional Water Reckamation Facility - 12751 Hagen Ranch Rd. West Palm Beach, H.

Palm Beach County Water Tratement Plant 11/2ake Regional Water Treatment Plant-39700 State Rd. 80, Wellington, FL

Westem Regon North WasteWater Treatment Plant - foso MoClure Rd, Pahokee, H
Westem Regon WasteWater Treatment Plant - Wes Canal St, Belle Glade HL
} 


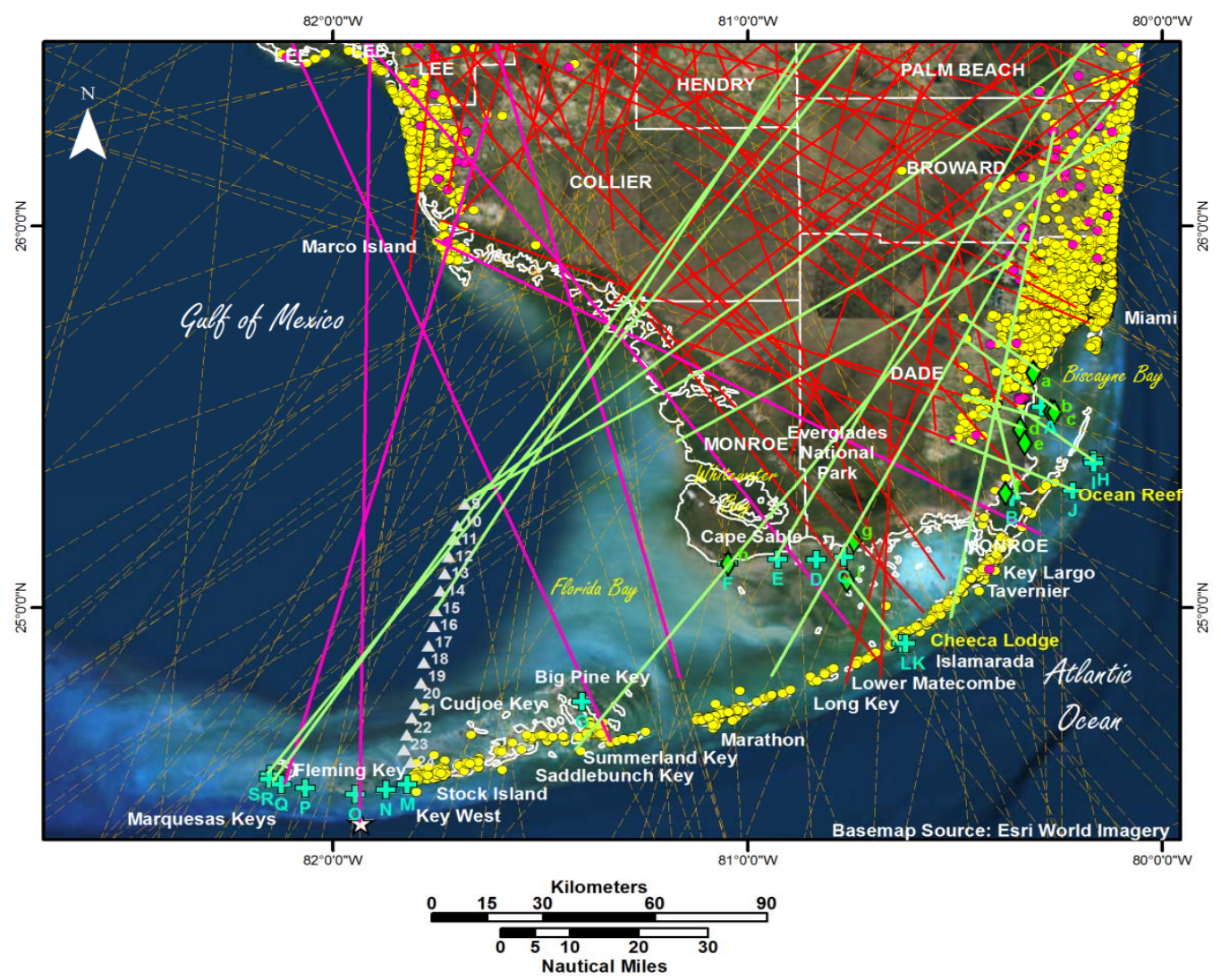

Figure 9. Locations of transformed analog lineaments in south Florida previously mapped by the Florida Department of Transportation as fractures (red diagonal lines) and extensions of those fractures (orange diagonal dashed lines) in proximity to the Class I (pink circles) and Class V (yellow circles) aquifer-injection wells and sample sites (as described in Figure 7)

Brand (2002, figures 13.51 and 13.52) reported a sharp increase in chl-a $\left(>1.5 \mu \mathrm{g} \mathrm{L}^{-1}\right)$ in his surfacewater Sites 14 and 15 in that vicinity, compared to other sample sites along his transect of 20 sample sites associated with the coral reefs that extend from Key Biscayne southwest to Marathon. Those samples were collected on November 4, 1997, during the rainy season, and the spike in chl-a was attributed to nutrient-contaminated surfacewaters flowing through the largest passes from Florida Bay and Hawk Channel to the ocean side of the Keys. Brand (2002) reported observed and documented plumes of turbid, low-salinity, nutrient-rich, high-chlorophyll surface water flowing from Florida Bay to the coral reefs, but the locations of fracture networks reported in our study were not accessible for consideration during that analysis of contaminated surface waters.

Although Brand (2002) addressed the possibility of sewage as a potential source of anthropogenic land-based nutrients contaminating Florida Bay, he rejected that hypothesis because he concluded that the "source of nutrients is downstream of the algal blooms, not upstream." The implied source of sewage in that conclusion was sewage generated on the Florida Keys. The extensive network of intersecting fractures throughout Florida Bay and the extent of our study area suggests that SGD of sewage effluent in Florida Bay not only could be originating from aquifer injections in the Florida Keys, but also from the injection wells identified in Table 2 that are associated with fractures extending through Florida Bay. Additional analyses in the Hawk Channel area of Florida Bay and ocean-side and other areas with fractures, particularly during the dry season, may confirm that SGD contaminated with aquifer-injected sewage effluent is contributing to the turbid, low-salinity, nutrient-rich, high-chlorophyll surface water flowing from Florida Bay to the coral reefs.

The fracture extensions bracketing the Marquesas Keys suggest that aquifer-injected sewage effluent from the Marco Island wastewater treatment plant in Collier County, in addition to aquifer injections in Martin and Palm Beach Counties could be contributing to eutrophication and other surfacewater degradation at those sites (Figure 9 and Table 2). Aquifer injections at the Marco Island facility were occurring as early as January 1, 1991, according to the FDEP's spreadsheet records. Aquifer injections of sewage effluent at those locations, transported through fractures, could explain the isotopic signature in surfacewater samples indicative of a large 
component of deep (Floridan) SGD and a $\delta^{15} \mathrm{~N}$ signature in the benthic algae characteristic of sewage effluent. Focused SGD of injected sewage effluent from those fractures also could be fueling the growth of benthic macroalgae at Sites Q, R and S. Site R was the shallowest site in our study (in Mooney Harbor Key) and Site Q was the site with a previously living coral head that declined and died shortly before collection of samples for this study.

Injected sewage effluent discharging from fractures as SGD in that vicinity also could explain the large-scale stratification described as a layer of cold, "dirty" turbid water $\sim 9-12 \mathrm{~m}(30-40 \mathrm{ft})$ thick, moving along the bottom at the outer edge of a reef (total depth $\sim 30 \mathrm{~m}$, white star south of Site O in Figure 9). That event was described in Don DeMaria's letter dated February 10, 1994 to the Chairman of the FKNMS.

Fracture extensions in the immediate vicinity of Site 9, west of the northern tip of Cape Sable where the abnormal (inverted) salinity stratification was documented, are associated with deep-injection wells in Broward and Palm Beach Counties (Figure 9 and Table 2). Those fractures also intersect with a network of fracture extensions oriented northwest into Collier County and southeast to the injection wells in the Keys, which also could be contributing to SGD containing sewage effluent and other contaminants.

Sites 14, 15 and 16 in the chl-a transect from that depressional feature west of Cape Sable to Fleming Key (Figure 9) had chl-a levels that exceeded $2 \mu \mathrm{g} \mathrm{L}^{-1}$ and were greater than chl-a levels at Site 17, which was closer to Fleming Key. The chl-a levels at Sites 14-16 may have resulted from the alignment of Site 15 with the fracture that extends SW from the Class I injection well at the Western Region North Wastewater Treatment Plant located at the SW corner of Lake Okeechobee, in Palm Beach County. Site 15 is located at a fracture intersection and Site 14 is within $5 \mathrm{~km}(3.1 \mathrm{mi})$ of fracture intersections that includes the fracture at Site 15 (Figure 9, Table 2). Those fracture intersections could have been contributing focused SGD with elevated nutrients at those sites when those samples were collected.

Site 9, where the depressional feature west of Cape Sable was documented, appears to be the same vicinity where a high density of turtle grass (Thalassia testudinum Banks ex. König) was reported in the South Florida seagrass-distrubution study by Fourqurean, Durako, Hall, and Hefty (2002, figure 18.6). This suggests that turtle grass may be an indicator species of groundwater discharge, similar to the plants indicative of focused groundwater discharge described by Rosenberry, Striegl, and Hudson (2000). Seagrass data in the study by Fourqurean, Durako, Hall, and Hefty (2002) were collected within the boundaries of the FKNMS during the summer of 1996 and 1997; north of the FKNMS near Cape Romano, Key West and Florida Bay during August 1998 (as part of the FKNMS program); and within Florida Bay during the summer of 1998. The seagrass data were collected using the stratified random method of hexagonal tessellation developed by the USEPA's EMAP program. A krigging algorithm was used to interpolate between the point data on species density to produce continuous maps of density of seagrass species in that study. Those study designs and methods presume homogeneous conditions and do not account for focused discharge of ground water (e.g., from fractures and submerged sinkholes) that may provide nutrients and contaminants that are beneficial to some species and detrimental to other species. That seagrass study addressed the causes of seagrass dieoff in Florida Bay, referenced the monitoring and research program initiated by FDEP in 1995 to provide spatially comprehensive status and trends information on the benthic communities of Florida Bay and identified a pathogen, sulfide toxicity and salinity as factors in the seagrass dieoff. It is important to note that the seagrass study by Fourqurean, Durako, Hall, and Hefty (2002), the FDEP monitoring and research program, the USEPA's EMAP program and the FKNMS program all failed to consider focused groundwater discharge, groundwater seepage and waste water injected into wells associated with the highly fractured submerged areas evaluated in those studies as a source of pathogens, sulfide and salinity disruptions.

Fractures extending from aquifer-injection wells on the west coast and east coast also could be contributing to areas in Whitewater Bay and Florida Bay that exhibited extremely low salinities during the dry season (February to April) from 1996 through 2000, when freshwater from surfacewater discharges are limited (Figure 10A, red and orange). During that same period other areas of Biscayne Bay and the vicinity of the ocean-side reefs exhibited areas of anomalous hypersaline (38-45 ppt) water (Figure 10A, dark blue). Those anomalous areas of hypersaline water could result from SGD from those fractures of native hypersaline water from the lower Floridan aquifer system, being displaced by aquifer injections of sewage effluent (Table 2). Injected sewage effluent also may be resulting in SGD from fractures responsible for nutrient loading contributing to the high chl-a levels documented in Whitewater Bay and surrounding Cape Sable during that same time period (Figure $10 \mathrm{~B}$, orange and dark red, Table 2). The previously unpublished averages in the inserts of Figures $10 \mathrm{~A}$ and $\mathrm{B}$ were plotted by Larry Brand using fixed-radius surface interpolation. Brand (2002) provides a detailed discussion of seasonal variations in salinity and chl-a in that area. Similarly, high radon excesses indicative of 
deep ground water in coastal waters of Key Largo may be the result of focused SGC from fractures associated with aquifer-injection wells in Broward and Dade Counties (Figure 10C, Table 2).

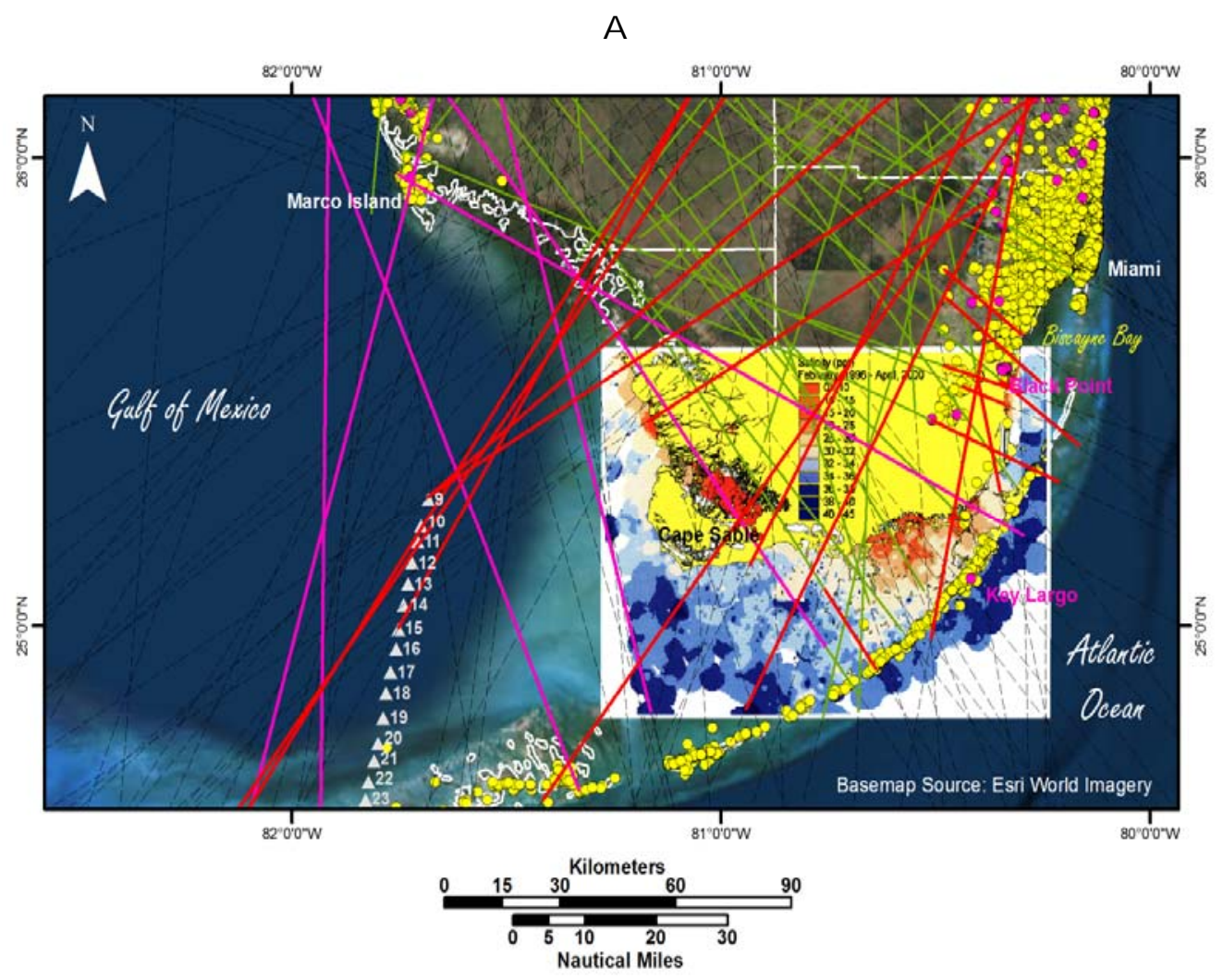

B

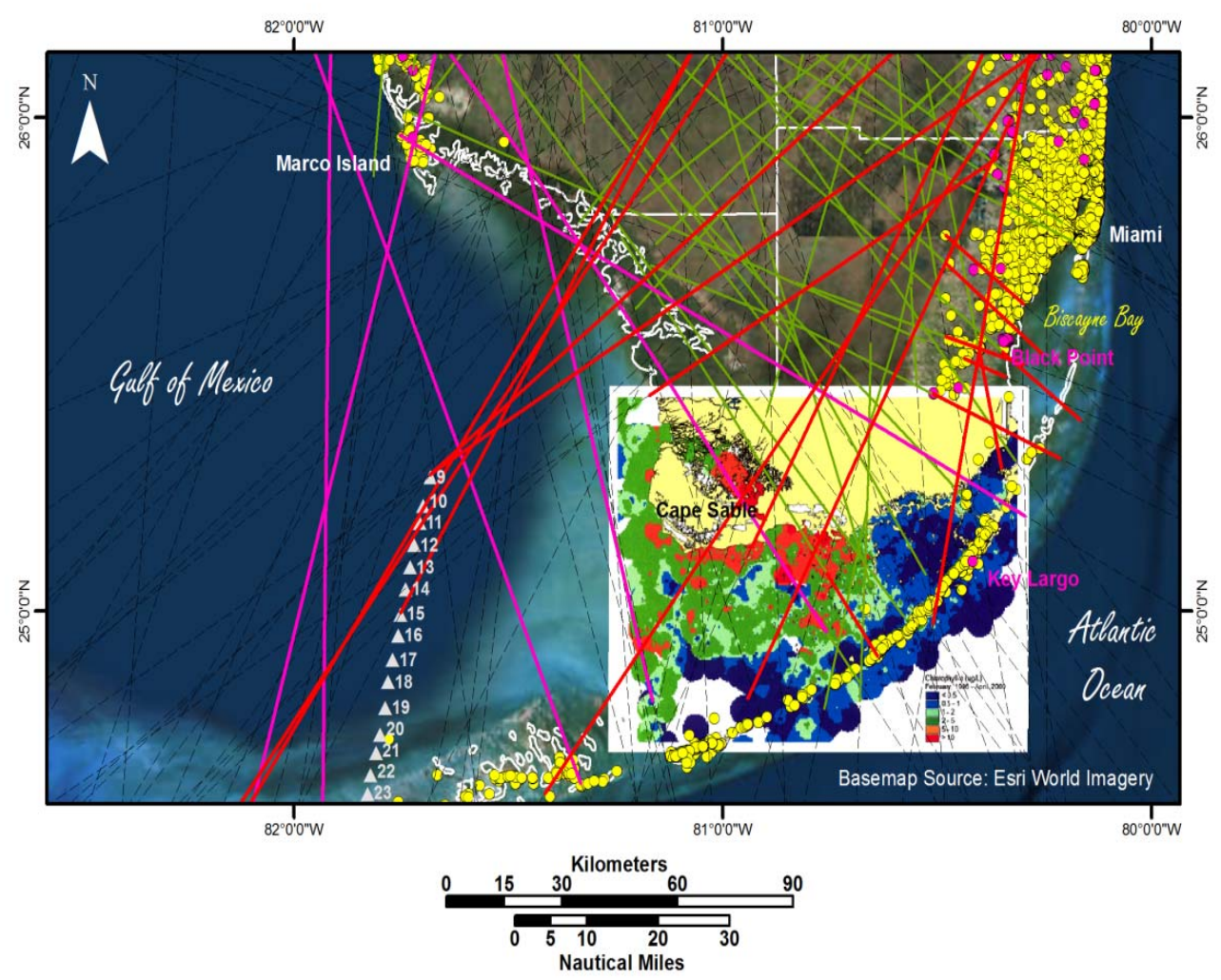




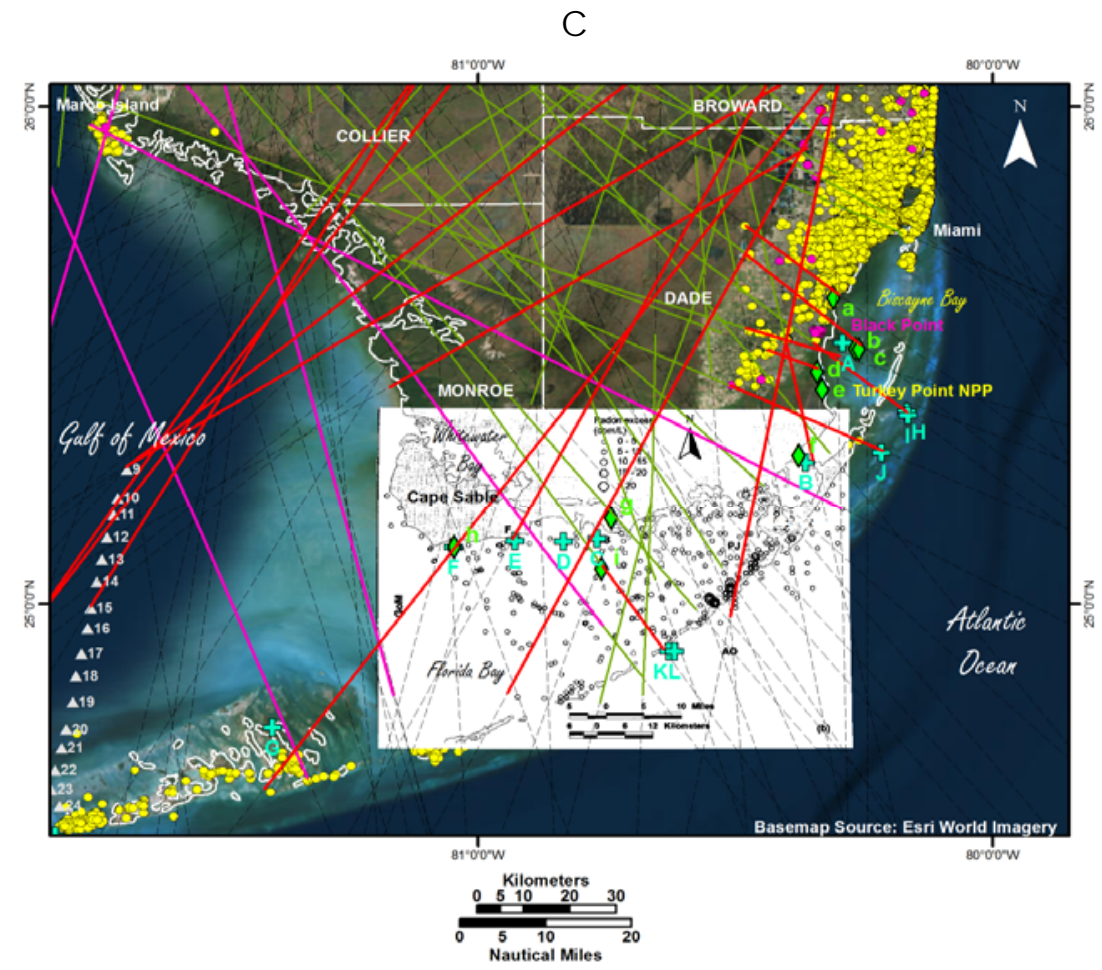

Figure 10. Fractures and fracture extensions (diagonal lines as described in Figure 9) and aquifer-injection wells (circles) in proximity to surfacewater averages during the dry season (February to April) from 1996 to 2000 for: A. salinity (ranging from dark red $=0-10 \mathrm{ppt}$ to dark blue $=40-45 \mathrm{ppt}$ ) and B. chl-a (ranging from dark blue $=$

$<0.5 \mu \mathrm{g} \mathrm{L}^{-1}$ to dark red $=>10 \mu \mathrm{g} \mathrm{L}^{-1}$ ) C. radon excesses (ranging from 0 to $>20 \mathrm{dpm} \mathrm{L}^{-1}$ ) (inserted mapped results for salinity and chl-a courtesy of Larry E. Brand, University of Miami, Rosenstiel School of Marine and Atmospheric Science; inserted mapped results from Top, Brand, Corbett, \& Burnett (2001) for radon excesses reproduced with permission from the Journal of Coastal Research)

\section{Discussion}

\subsection{Mapped Lineaments Indicative of Fractures and Associated Sinkholes}

The extensive use of lineaments to locate fractures and associated subsidence features (e.g., sinkholes) was summarized by Lines et al. (2012). For example, Littlefield, Culbreath, Upchurch, and Stewart (1984) specifically addressed the association of sinkhole development in Florida and how sinkholes can occur along these linear features and conduits of any scale over geologic time. Popenoe, Kohout, and Manheim (1984), also investigating the regional karst Floridan aquifer in Florida, emphasized the non-random distribution of solution features controlled by regional joint patterns. Although fractures mapped as lineaments generally are illustrated over landmasses, their research used geologic methods to tract submarine extensions of these land-based lineaments to confirm that these fractures extend beyond the present-day shoreline, in the submarine platform of the Floridan aquifer, also known as the Florida shelf. The dissolution of Eocene and Oligocene rocks follows fractures that are caused by deep collapse. This results in the propagation of sinkholes to the surface through the overlying Neogene section along these trends. Their research along Florida's east coast emphasized the fact that the most pronounced deformation from solution follows the reef and back-reef edge of the Late Cretaceous Paleocene carbonate platform and that the collapse and filling of submarine sinkholes continues today (Popenoe, Kohout, \& Manheim, 1984). More recently, Raabe and Bialkowska-Jelinska (2010) extended lineaments mapped in the vicinity of Citrus and Levy Counties, Florida to submerged areas of the Floridan aquifer in near-shore waters of the Gulf of Mexico as part of the evaluation of thermal infrared (TIR) areas indicative of groundwater discharges.

Also well established is the fact that submarine springs in Florida's coastal waters historically discharged fresh water generated from Florida's karst aquifer system and that those discharges attracted large numbers of coastal fish. Popenoe, Kohout, and Manheim (1984) discussed examples that included a submarine spring off-shore of 
Crescent Beach, Florida that produced 2250 kilograms (5000 pounds) of red snapper (Lutjanus aya) to one fisherman in 1962 and $450 \mathrm{~kg}(1000 \mathrm{lb})$ of red snapper to another fisherman in 1968 . Unfortunately, by the time a fluorescein dye sample was released in the sinkhole in 1970, fresh groundwater discharge had ceased and the downward movement of the dye suggested saltwater intrusion into the Floridan aquifer was occurring at the site of the former spring due to groundwater extractions.

Kincaid, Davies, Werner, and DeHan (2012) used fluorescent dyes to conduct a tracer study in northwest Florida at eight stations associated with the City of Tallahassee's municipal sewage effluent spray field (Southeast Farm Wastewater Reuse Facility) in Leon County. The springs included Wakulla Spring in the state park and Indian, Sally Ward and McBride Slough springs, all located in Wakulla County. The velocities for the eight stations in that study were "maximum recorded flow rate: $998 \mathrm{ft} / \mathrm{day}$; average recorded flow rate: $688 \mathrm{ft} /$ day." Five of the eight stations were located $\sim 17.7 \mathrm{~km}$ (11 mi), straight-line distances. Those estimates were considered as minimum velocities because they assume a straight-line flow path, but that study did not incorporate the locations of fractures in the vicinity of Leon and Wakulla Counties and did not consider flow through fractures, which could account for southwest flow at different velocities from southwest flow via sinuous dissolution conduits linked to Wakulla, Indian, Sally Ward and McBride Slough springs. The fact that the appearance of fluorescent compounds associated with the St. Marks River, southeast of the sprayfield, was not similar to the flow responses to southwest sites suggested the need for additional research to confirm flow to the southeast from the sprayfield (Todd Kincaid, pers. com., December 2013). The conclusions from the study by Kincaid, Davies, Werner, and DeHan (2012) supported the findings of Bacchus and Barile (2005) that treated sewage effluent is the primary source of nitrogen pollution fueling the growth of alien, invasive and nuisance vegetation in Wakulla Springs.

\subsection{Conduit v. Diffuse Discharge}

At the end of 2006, the USEPA reported the largest number (112) of Class I "non-hazardous" deep-aquifer injection wells nationally, with possibly as many as 10 of the nation's 51 Class I hazardous injection wells located in Florida, but the locations of those wells were not provided (http://water.epa.gov/type/groundwater/uic/wells_class1.cfm). Bacchus (2001, Figure 1) illustrated the distribution of 80 Class I deep-aquifer injection wells identified in 1999. At that time, more than 8,000 Class V injection wells reportedly occurred in Florida at unspecified locations. Subsequently, FDEP permitted additional aquifer-injection wells and provided an on-line interactive map of injection wells that distinguish ASR injection wells from other injection wells (http://ca.dep.state.fl.us/mapdirect/?focus=uic). That interactive-map site includes a disclaimer that states "Neither the State of Florida, nor the Florida Department of Environmental Protection (FDEP), makes any warranty, expressed or implied, including the warranties of merchantability and fitness for a particular purpose arising out of the use or inability to use the data, or assumes any legal liability or responsibility for the accuracy, completeness, or usefulness of any information, apparatus, product, or process disclosed, or represents that its use would not infringe privately owned rights." Repeated attempts to use the site to retrieve information on the injection wells resulted in reoccurring error messages. The additional aquifer-injection wells included, but were not limited to: three in the Florida Keys/Monroe County (Key West, Stock Island and Marathon); seven in West Palm Beach, Hillsboro Canal/Palm Beach County (SE Florida); three in Port St. Lucie, Broward and Brevard Counties (SE Florida); 19 in Sanibel, Ft. Myers/Lee County (SW Florida); 19 in Marco Island, Naples/Collier County (SW Florida); one in Boca Grande/Charlotte County (SW Florida); two in Sarasota and Pinellas Counties (SW Florida); six in Bradenton/Manatee County (SW Florida); and 12 in Tampa/Hillsborough County (SW Florida).

Although aquifer injections of treated effluent in both Class I and Class V wells are classified as non-hazardous by the USEPA, contaminants typical of treated effluent, such as those reported by Murphy et al. (2003), are known or suspected to be hazardous to marine and aquatic organisms, as summarized by Bacchus $(2001,2002)$. The mobilization of arsenic contained in aquifer formations has been documented in water samples in response to aquifer injections and withdrawals associated with ASR (Arthur et al., 2002; Price \& Pichler, 2004; Pyne et al., 2004). Seven ASR sites at the 13 operational ASR wellfields that were evaluated by the three primary consulting firms promoting ASR in Florida were documented as containing water with levels of arsenic that exceeded 10 $\mathrm{mg} \mathrm{L}^{-1}$ (Pyne et al., 2004), the maximum level for potable water.

Despite the problem with arsenic contamination, these types of aquifer injections and withdrawals, referenced in Florida as ASR, are considered benign and even environmentally beneficial by the regulatory agencies. Preferential induced discharges to sensitive near-shore areas and other surface waters of injected sewage effluent and agricultural and industrial wastes, co-mingled with arsenic-laden water from ASR injections and other underground contaminants, can occur through fractures and other karst conduits. These adverse environmental 
impacts have not been evaluated during the permitting process for these aquifer injection wells.

The volume of deep-aquifer injections in south Florida is proposed to increase by approximately twice the current volume, if the $\sim 330$ new ASR wells recommended for construction under the controversial Comprehensive Everglades Restoration Plan (CERP) are constructed. Injections into these wells would include agricultural and urban stormwater. Pilot projects to construct and test five of those ASR wells in the Everglades were proposed by the US Army Corps of Engineers (USACE, 2004a, 2004b). Those wells are in the vicinity of industrial waste injections into the lower Floridan aquifer at depths of $\sim 460$ to $580 \mathrm{~m}$ (1500 to $1900 \mathrm{ft}$ ) where contaminants were detected in a shallow monitor well within 27 months after injections began, then again within 15 months after injections had resumed (Kaufman \& McKenzie, 1975). The Everglades, where the 330 new ASR wells are proposed, is an integral part of the ecosystem incorporating Florida Bay, the Florida Keys, and the associated coral reefs.

The recovery efficiencies for ASR wells in south Florida, summarized by Reese (2002), were calculated using a chloride concentration of $250 \mathrm{mg} \mathrm{L}^{-1}$. This concentration presumably was selected because it is the limit for potable water under the federal Safe Drinking Water Act, under which aquifer injections are authorized. Chloride concentrations of injected water generally are $<250 \mathrm{mg} \mathrm{L}^{-1}$. The lowest recovery efficiencies reported in this summary were for ASR tests conducted in the Lake Okeechobee area proposed for use in the northern vicinity of the Everglades. Those reported recovery rates were $3.1 \%, 2.7 \%$, and $7.2 \%$ for "storage" periods of 0,8 , and 5 days, respectively (Reese, 2002). Actual recovery efficiency was lower, however, since chloride concentrations of injected recovery fluids for those aquifer injection tests were 150,100 , and $70 \mathrm{mg} \mathrm{L}^{-1}$, respectively. As additional support for the conclusions in our study, that injected fluids are subjected to rapid groundwater dispersal from the injection site, the actual recovery for the 18 ASR sites inventoried by USGS in southern Florida was determined by comparing the chloride concentration in injected during ASR cycle testing and in recovered fluids reported as recovery efficiency in Table 5 by Reese (2002) and adjusting those results to a 250 $\mathrm{mg} \mathrm{L}{ }^{-1}$ chloride level. The results of those adjusted recovery results were as follows, with ASR sites having reported recovery concentrations in Table 5 by Reese (2002) that exceeded twice the injected chloride concentrations shown in bold:

\section{East Coast:}

Broward/Broward 3-4\%

Springtree/Broward 7-10\%

Fiveash/Broward 2-3\%

Shell Creek/Broward 5-12\%

Manatee Road/Broward 1-6\%

Hialeah/Lee 9-12\%

West Well Field/Miami-Dade 2-14\%

Marathon/Monroe 1-12\%

Jupiter/Palm Beach 0-9\%

\section{Boynton Beach/Palm Beach 4-17\%}

West Palm Beach/Palm Beach NA (insufficient data to determine recovery)

St. Lucie/St. Lucie NA (insufficient data to determine recovery)

These extremely low recovery rates for such brief storage times support the conclusion that aquifer-injected fluids in south Florida are not being stored, but rapidly disperse via conduit rather than diffuse flow. Results from the ASR wells proposed for use in the northern vicinity of the Everglades provide supplemental support for the influence of the characteristic secondary permeability of the regional karst (Floridan) aquifer system that has been documented in previously referenced groundwater tracer studies.

Aquifer-injection of minimally treated sewage effluent in 2004 occurred via as many as 5000 shallow wells in the karst aquifer system throughout the narrow strip of land comprising the Florida Keys (Richard Deuerling, FDEP, pers. comm., March 2004). These shallow wells are cased to $\sim 20 \mathrm{~m}$ (reported in FDEP permits as $60 \mathrm{ft}$ ). Those shallow injection wells are permitted under the regulatory presumption that a laminated crust capping the Quaternary $3(\mathrm{Q} 3)$ marine unit is continuous and will prevent injected sewage effluent and other contaminants from resurfacing in near-shore waters (Jack Myers, FDEP, pers. comm., September 2000). The locations of these wells and details of injections were not readily available because not all of those wells were mapped and no comprehensive electronic or comparable database had been compiled. The more recent FDEP on-line, interactive map still does not include a comprehensive database because, for example, FDEP has no information about 
aquifer injections that were authorized by the county health departments or a comprehensive database for the depths and dates that aquifer injections were initiated for each aquifer injection well.

The Q3 is one of five marine units identified in Pleistocene rocks of south Florida that were deposited in response to eustatically controlled sea-level fluctuations. The Q3-Q5 units (oldest to youngest) are classified as Key Largo Limestone. Those Pleistocene rocks are known to exhibit discontinuities and are characteristically thin over the Cape Sable high, in the vicinity of the Florida Keys. Discontinuities include the absence of the laminated crust in updip areas (e.g., coral reef zones), which experienced erosion subsequent to formation, as well as areas of the Q3 where root structures have penetrated $6 \mathrm{~m} \mathrm{(20} \mathrm{ft)} \mathrm{downward} \mathrm{into} \mathrm{the} \mathrm{section} \mathrm{(Enos} \mathrm{\&}$ Perkins, 1977). Those commonly occurring discontinuities provide discrete, localized points where injected contaminants can discharge to surface waters, via conduit flow. Those points of discharge can coincide with environmentally sensitive areas such as coral reefs.

At the time of the sample events in our study, more than 1000 Class V wells were injecting contaminants throughout the Florida Keys primarily into the shallow aquifer at depths of $\sim 20 \mathrm{~m}$. Exceptions were deep-aquifer

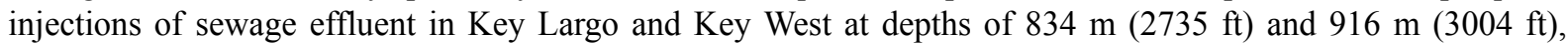
respectively. In addition to those deep-aquifer injections in the Florida Keys, a cluster of 17 Class I wells injected secondarily treated municipal sewage effluent into the regional Floridan aquifer system immediately north of the Keys, at the Miami-Dade South District Wastewater Treatment Plant (aka Black Point) injection well field. The aquifer-injection wells at Black Point remain active, represent the largest municipal sewage injection facility in Florida and are located $\sim 1.6 \mathrm{~km}(\sim 1 \mathrm{mi})$ west of Biscayne Bay and Biscayne National Park. The injection capacity for Black Point injection wells 1-13 was reported in the permit issued May 15, 2001 (61787-014-UC) as 787,367 $\mathrm{m}^{3}$ day $^{-1}$ (208 $\left.\mathrm{mgd}\right)$ at a depth of $732 \mathrm{~m}$ (2403 ft).

Multiple monitoring wells at the Black Point, Miami-Dade injection facility revealed contaminants from the injected sewage effluent have reached overlying zones of the upper Floridan aquifer since 1994. The USEPA began issuing warning letters and notices of violation to Miami-Dade for the violations at that facility in 1994. In 1997, the USEPA issued a consent order to Miami-Dade, requiring the municipality to conduct studies of the area. Those studies confirmed that the injected sewage was not contained within the designated injection zone in the lower Floridan aquifer system (USEPA, 1997). Despite the documented flow from the injection zone, in violation of federal law, the facility continued to inject minimally treated sewage effluent, with permitted volumes increased levels (reported as $112.5 \mathrm{mgd}$ ) under Consent Orders from FDEP issued on March 12, 1999 (No. 94-3659) and April 29, 2004 (No. 03-1376).

The upward flow of injected wastes at the Miami-Dade Black Point facility was not the first occurrence of this type. An industrial injection well also located in southeast Florida (Belle Glade) began injections into the lower Floridan aquifer, at depths of $\sim 460$ to $580 \mathrm{~m}$ (1500 to $1900 \mathrm{ft}$ ), in December 1966. Within about 27 months after injections began, the wastes had "migrated" upward to a shallow monitor well. Within 15 months after injections had resumed, at a greater depth $(683 \mathrm{~m}$, or $2242 \mathrm{ft})$, the wastes again were detected in a shallow monitor well. The increased hydrogen sulfide in the shallow monitor wells, detected as a front several months prior to the arrival of the injected waste in the shallow monitor well, was attributed to the oxidation of injected organic waste by anaerobic bacteria, which may have resulted from reduction of organic matter to hydrogen sulfide. Decrease in the sulfate-chloride ratio associated with sulfate reduction (and increase in hydrogen sulfide) was suggested as a sensitive indicator of waste migration. The groundwater circulation, preferential pathways for the lateral and upward movement of wastes, and lack of confinement documented in that study led to the conclusion that potential conflicts exist in the use of the Floridan aquifer for waste disposal and subsequent use as a natural resource (Kaufman \& McKenzie, 1975).

Deep aquifer-injection of sewage effluent and industrial waste theoretically is conducted under the most stringent conditions for aquifer injections in Florida. If those injections are not capable of being contained, similar injections into the upper Floridan or surficial aquifer zones, such as the $\sim 1500$ shallow injection wells permitted by the FDEP in the Florida Keys, also should be presumed to have flowed beyond the injection location.

Similar deep-well injections were occurring on Fleming Key under test conditions authorized in a permit issued to the City of Key West by FDEP on June 6, 2001 (Cert. No. 63207-209-UC). Backup injections are directed to a shallow ( $20 \mathrm{~m}$, reported as cased to $60 \mathrm{ft}$ below pad level) Class V, group 9 well at the same location. The City of Key West was permitted to receive operational status to inject $68,137 \mathrm{~m}^{3}$ day $^{-1}$ (reported as $18 \mathrm{mgd}$ ) of secondarily treated municipal sewage effluent into the karst Oldsmar Fm ( 1000 m deep), via a Class V injection well (IW-1, FDEP 203674001-UO), with intended upgrade to advanced wastewater treatment (AWT), but FDEP's spreadsheet database did not include that permit number. 
Despite the documented failure of both shallow and deep injection wells to meet federal regulations, the Federal Emergency Management Agency (FEMA, Charles Beck, pers. comm., March 2004) authorized $\sim \$ 12$ million in federal funding for the construction and operation of a centralized sewage system to convert private sewage systems to aquifer-injection systems in the Florida Keys. Service area conversion locations included Bay Point and Saddlebunch Key $(\$ 3,016,8480$, on Bay Point Key), Islamorada $(\$ 1,976,250)$, Key Largo $(\$ 5,485,714)$, and Conch Key $(\$ 1,394,215)$. Aquifer injections for those facilities primarily are via shallow Class V injection wells (reported as cased to $60 \mathrm{ft}$ below land surface). The two Bay Point/Saddlebunch wells would be located $\sim 21.6$, 16 , and $1.6 \mathrm{~km}(\sim 10,13.5$, and $1 \mathrm{mi})$ northeast of the deep and shallow injection wells on Key West, shallow injection wells on Stock Island, and shallow injection wells on Saddlebunch Key, respectively. The FDEP's spreadsheet database did not include a deep aquifer-injection well on Key West.

Those large-scale conversions from septic tanks and cess pits to aquifer-injection of sewage effluent and stormwater are being federally funded, permitted and constructed in the absence of any comprehensive scientific evidence that these aquifer-injections reduce nutrient loading and the discharge of other contaminants in Florida Bay, Gulf of Mexico, and ocean-side near-shore waters. Some small-scale studies in the Florida Keys have shown that nutrients leach from septic tanks and cess pits into canals, and that tracers flushed into some septic tanks entered canals. In at least three separate field experiments in the Keys, however, tracer solutions flushed into septic tanks resulted in the tracer never being detected in surface waters (Paul et al., 2000; John Paul, pers. comm., December 2000).

In one experiment where the tracer from the septic tank was not detected in surface water, the same type of tracer was introduced into a shallow injection well at the Saddlebunch Key site. That experiment was conducted adjacent to the proposed FEMA injection well site. The tracer from that shallow-aquifer injection well traveled southeast, toward the reef tract on the ocean side, at rates up to $141 \mathrm{~m} \mathrm{~h}^{-1}\left(463 \mathrm{ft} \mathrm{h}^{-1}\right)$. The flow rate of effluent injected into the shallow carbonate aquifer of the Keys for a 24 hour period, based on the data from Paul et al. (2000), would be $\sim 3.4 \mathrm{~km} \mathrm{~d}^{-1}\left(2.1 \mathrm{mi} \mathrm{d}^{-1}\right)$. No similar tracer studies have been conducted to evaluate deep-aquifer injection wells. Likewise, no studies have been conducted to determine the fate of shallow or deep aquifer-injected wastes.

\subsection{Integrated Samples v. Point Samples}

Point samples of surface water and ground water commonly are used to evaluate the presence of nutrients such as $\mathrm{N}$ and $\mathrm{P}$ in vast near-shore coastal areas, but those samples represent only conditions at that instant in time. Samples of macroalgae, however, represent a temporal integration of available nutrients at each sample site. For example, environmentally significant pulses of SGD, whether originating from surface or submarine sources, are much less likely to be reflected in periodic (e.g., weekly, monthly, seasonal) samples of water than in periodic samples of benthic macroalgae. Variations in benthic macroalgal $\delta^{15} \mathrm{~N}$ ratios at specific sites within the study areas should be expected to occur between wet and dry seasons, with surfacewater contamination increasing during the rainy season. The samples in our study were collected during the rainy (wet) season.

In a separate research project in Palm Beach County, Florida, north of our study area, macroalgal and water column samples were collected during the dry (May) and wet (August) seasons of 2001. The objective in that multiseasonal study was to evaluate areas of extensive benthic macroalgal growth engulfing reefs in that coastal county, where one of the oldest deep-aquifer sewage injection sites in Florida is located in West Palm Beach. More specifically, the objective of that study was to identify the relative importance of various $\mathrm{N}$ sources fueling the algal growth (e.g., fertilizers, sewage effluent, natural upwellings), not the identification of transport mechanisms, however, the researchers in that study noted that one pathway for transport of sewage-derived $\mathrm{NH}_{4}^{+}$ (and $\mathrm{NO}_{3}{ }^{-}$) to the mid-depth and deep reefs is SGD from Class I and Class V injection wells. The study was initiated because of concern over the proliferation of that harmful macroalgal bloom was based on the adverse impacts on shallow $(\sim 4 \mathrm{~m})$, mid-depth $(\sim 25 \mathrm{~m})$, and deep $(\sim 43 \mathrm{~m})$ reefs. Macroalgal $\delta^{15} \mathrm{~N}$ analysis was used to determine that human sewage was the source of nitrogen being used to fuel abnormal growth and spread of these harmful algae (Lapointe \& Barile, 2001).

In that study area, Class I injection-well facilities reportedly dispose of secondarily treated wastewater, with high concentrations of $\mathrm{NH}_{4}{ }^{+}$, to depths of $\sim 1000 \mathrm{~m}(\sim 3280 \mathrm{ft})$. Class $\mathrm{V}$ wells in that study area are used to inject primarily stormwater runoff, at discharge depths of $<30 \mathrm{~m}(<98 \mathrm{ft})$. The relative lack of $\mathrm{N}$ from rainfall, stormwater runoff, and upwelling during the May blooms, combined with statistically similar $\delta^{15} \mathrm{~N}$ values of macroalgal samples from the May (non-upwelling) and August (upwelling) samples supported the conclusion that sewage was the source of $\mathrm{N}$ resulting in the macroalgal blooms in that area (Lapointe \& Barile, 2001). The depth of injected effluent, the depth of the reefs and the buoyancy of the nonsaline sewage effluent, provide 
combined support for the conclusion that the source of the sewage signature in macroalgae from mid-depth and deep reefs at that location is SGD from deep-aquifer injection wells, via karst conduit flow.

\subsection{Mechanisms of Subsurface Discharge and Distribution}

The saline injection zone where the municipal waste (sewage effluent) is injected at the Miami-Dade Black Point facility occurs at depths comparable to the bottom of the Straits of Florida, $>800 \mathrm{~m}$ ( $2500 \mathrm{ft}$ ), as was the case for the industrial discharges at the Belle Glade facility, depicted in figure 2 of Kaufman and McKenzie (1975). The Straits of Florida extend from the ocean side of the Florida Keys northward along the east coast of Florida, past the Black Point injection facility to approximately the western extent of the Bahamas. During seasonal upwelling events along the southeast coast of Florida, cool water from the depths of the Straits and the Gulf Stream north of the Straits flows upward and onto the shelf (Figure 3). In the summer of 1978, an upwelling event began in mid June and continued until early September in the vicinity of Ft. Pierce, Florida (Smith, 1981; 1982b), which is located approximately midway between the site of this study and the study conducted by Barile (2004). Similar events of varying duration have been recorded in response to Hurricane David in September 1979 (Smith, 1982a) and in the summer of 1980 (Smith, 1983).

Although subsurface discharge of large volumes of injected sewage effluent and other fluids may not cause upwelling events along the coast of south Florida, those aquifer injections provide a mechanism to distribute deep-aquifer injected contaminants along the depths of the Florida Straits and preferentially discharge those contaminants, during upwelling events and via SGD, over sensitive benthic organisms such as corals. Corals and similar organisms are unable to escape to more favorable conditions. The distribution of injected contaminants, resurfacing at considerable distances from the injection site and at depths where upwelling is initiated, could explain phenonmena throughout the Straits that are similar to the wall of cold turbid water observed in the vicinity of the Marquesas Keys that moved along the bottom at the outer edge of a reef in the vicinity of the Marquesas Keys, described by Don DeMaria in his1994 letter to the Chairman of the Florida Keys National Marine Sanctuary.

Based on the mechanisms for distribution of injected effluent in coastal waters, induced discharges may occur throughout the submerged carbonate platform and along its margin, resulting in re-distribution of the injected contaminants in near-shore and surfzone areas during upwelling events. There is a potential for both shallow and deep aquifer-injected effluent and other fluids to cause induced discharges of native (formation) ground water, as well as induced discharges of the injected fluids and co-mingled contaminants. Additional research is needed to identify areas of preferential SGD throughout the study area and all other areas of aquifer injections.

One of the questions that have not been addressed is whether SGD nutrient loading from aquifer injections in the study area also may be capable of supporting planktonic algal blooms in the absence of, or in combination with surfacewater discharges from the "upstream" watershed. There is a widely held perception that nutrients (particularly P) in injected effluent are adsorbed to the calcareous rock (chemically scavenged or otherwise removed). This perception appears to be based solely on sample-scale assumptions of Darcian flow, rather than crustal-scale conduit flow conditions which are known to occur throughout the aquifer system underlying the study area and throughout the Floridan aquifer system, with subsequent discharge to near-shore waters, as described above. Brand (2002) demonstrated that $\mathrm{P}$ is the limiting nutrient in some parts of the study area (e.g., Florida Bay and associated Sounds). Therefore, groundwater transport of $\mathrm{P}$ also must be evaluated.

\subsection{Subsurface Contaminant Loading}

Anthropogenic sources of bioavailable, primary nutrients $\mathrm{N}$ and $\mathrm{P}$ are the cause of abnormal proliferation (blooms) of both microalgae (e.g., Florida red tide (Karenia brevis)) and macroalgae (e.g., sea lettuce (Ulva lactuca)) in coastal waters of the United States. Therefore, inferences about nutrient-related contaminant loading can be made when these eutrophication indicators are present, even in the absence of an extensive water quality database. The increase in anthropogenic nutrient loading also results in other seemingly diverse coastal problems, including fish kills, marine mammal deaths, outbreaks of shellfish poisonings, loss of seagrass habitats, coral reef destruction, and the Gulf of Mexico's dead zone (National Research Council, 2000). Anderson et al. (2002) provided an extensive review of the literature relevant to the role of eutrophication in HABs.

Some of the critical factors potentially influencing both nonaquifer-injected and aquifer-injected contamination of near-shore waters that were not addressed in the small-scale studies in south Florida referenced above include those described by Arthur et al. (2002), Bacchus (2001, 2002), and Pyne et al. (2004). Examples of those critical factors include the potential for significant uptake of nutrients and other contaminants by terrestrial vegetation from noninjection systems (e.g., septic drainfields) and the increased velocity and transport distance of undiluted contaminants from injection systems in south Florida. Those factors suggest that aquifer injection of 
contaminants can increase, rather than decrease nutrient loading and cause increases in other contaminants that were present in ground water from leaching or other sources. This subsurface contaminant loading could be responsible for the recent, rapid degradation and decline of Florida Bay and the Gulf of Mexico, as well as ocean-side near-shore waters and biota in south Florida. In the absence of a comprehensive evaluation of the impacts of these aquifer injections, there is no scientific support for the conclusion that aquifer-injection of contaminants, including nutrient-laden sewage effluent, will reduce sewage-related nutrient loading or otherwise improve the quality of near-shore waters.

These aquifer-injections also may result in subsurface transport of contaminants to and from mine pits, including those being used as sources for municipal water, also known as "reservoirs." For example, the fracture in the vicinity of Sites b and c, associated with multiple injection wells in Dade County, also transects mine pits in that county. Those pits also are intersected by another fracture, which is assocated with injection wells in Broward County and Site C. Multiple mine pits in Broward County and northeast Dade County also are intersected by a fracture associated with 10 injection wells in Broward County and Sites F and h. Additionally, the fracture that extends from the J. Rober Dean injection well in Dade County to Site J intersects the network of excavated cooling canals for the Turkey Point Nuclear Power Plant (Figure 9, Table 2).

The intimate interconnection between various deep and shallow aquifer layers (via fractures, dissolution/collapse features, paleochannels, and other discontinuities) and overlying surface waters, including wetlands in the Floridan aquifer system, has been established in the scientific literature (summarized by Bacchus, 2000a, 2000b, 2002). Fink1 \& Charlier (2003) illustrated localized areas of SGD associated with the 1st, 2nd, and 3rd reef tracts in southeast Florida (from nearest to farthest from shore, respectively). That illustration was revised by Krupa and Gefvert (2005) and also depicted an additional area of higher hydraulic conductivity $\left(>64.08 \mathrm{~m} \mathrm{~d}^{-1}\right)$ in the upper layer of the Tertiary Floridan aquifer system at the edge of the carbonate shelf, below the deepest (3rd) reef tract (Figure 2). This general scenario is applicable throughout south Florida's coast, although live coral reef formations are not predominant along the southwest Florida shoreline. The Figure 1B depicts the alignment of the Florida Reef Tract's deep reefs, extending along the $\sim 20 \mathrm{~m}$ (reported as $60 \mathrm{ft}$ ) depth contour, from the northern extent of Biscayne Bay (Fowey Rocks to Sand Key). That figure also depicts the $\sim 200 \mathrm{~m}$ (reported as $600 \mathrm{ft}$ ) depth contour of south Florida along the margin of the carbonate platform (identified as the Florida Plateau), where a significant volume of SGD historically occurred from deep-aquifer discharge. A summary of the literature describing the aquifer and historic flow characteristics was provided by Bacchus (2000a).

Recent evaluations exemplify the magnitude of subsurface contaminant loading to coastal waters in southeast Florida. Based on considerations of surfacewater and groundwater contributions of total $\mathrm{N}$ and $\mathrm{P}$ delivered to coastal waters of Palm Beach County, Florida, N and P from SGD (reported as 5727 and 415 metric tons per year, respectively) were determined to be $>2$ times the contribution from surfacewater discharges (Finkl \& Charlier, 2003). Surfacewater contributions were determined from canal discharges, while groundwater contributions were based on Darcy flow, evaluated by seepage meters. Localized discharges of ground water, via preferential karst conduit flow, may provide significantly greater values than the estimates based on SGD from diffuse flow. Spatial and temporal variations in karst conduit SGD, however, complicate attempts to estimate nutrient fluxes from groundwater discharges to near-shore waters at a larger scale. Finkl \& Charlier (2003) hypothesized that the primary source of the excessive SGD nutrient loading from diffuse flow in their Palm Beach County study area was from the inland Everglades Agricultural Area.

Stable nitrogen isotope ratios $\left(\delta^{15} \mathrm{~N}\right)$ in benthic macroalgal samples can provide a fingerprint of the anthropogenic source of $\mathrm{N}$ in nutrient loading. For example, May and August 2001 samples from the same general area addressed by Finkl \& Charlier (2003) were analyzed using the $\delta^{15} \mathrm{~N}$ technique. Those data supported the conclusion that human sewage was the source of $\mathrm{N}$ for macroalgae covering reefs in that area (Lapointe \& Barile, 2001). A similar analysis of harmful macroalgal blooms in coastal waters associated with the barrier island north of Palm Beach County also revealed that macroalgae from all seven sample sites exhibited an $\mathrm{N}$ signature indicative of sewage effluent, rather than signatures indicative of fertilizer, natural upwelling events, or $\mathrm{N}$-fixation (Barile, 2004). Nutrient concentrations of water samples collected in March, June, August, October, and December at the same sites where macroalgal samples were collected revealed dissolved inorganic nitrogen (DIN) concentrations at or exceeding the $1 \mathrm{mM}$ DIN threshold value for HAB formation for 27 of the 35 samples (Barile, 2004). These findings are noteworthy and suggest the source of nutrient loading is relatively constant, because the water samples are point samples rather than integrated samples, as are the macroalgae.

Contributors of sewage- $\mathrm{N}$ associated with that barrier island study in Brevard and Indian River Counties, reported by Barile (2004) in tonnes per day $\mathrm{N}$ and million liters per day discharge, were respectively: 1.14 for deep-well injection (56.8); 0.74 for percolation ponds and subsurface drainfields (35.7); and 0.06 for septic tanks 
(1.2). Those values indicate that deep-well injection of sewage effluent on the narrow strip of land constituting the barrier island represents $59 \%$ of the total 1.94 tonnes per day reported contribution. That significant sewage-based source of $\mathrm{N}$ is presumed not to discharge to the sensitive coastal waters surrounding the barrier island. The south beaches' central wastewater treatment facility in that study area, with a reported permitted capacity of 36 million liters per day, has been identified by EPA as a facility with "the potential for significant vertical migration of effluent" (USEPA, 2003). The injected effluent, constituting 61\% of the total volume of effluent discharge in the study area, is concentrated at two locations on the barrier island, where it is injected into the regional karst Floridan aquifer system. This procedure may result in the subsurface discharge (via conduit flow) to coastal waters of a much greater volume of sewage effluent than the remaining volume of sewage effluent from septic tanks, percolation ponds, and subsurface drainfields combined (via Darcian flow through the silica sand surficial aquifer of the barrier island). Results of our study and the referenced studies suggest that aquifer injections may be a significant factor in coastal nutrient loading in south Florida and those results also support the need for a more expansive study modeled after this study and including tracers.

\section{Summary and Conclusions}

Deep and shallow aquifer-injection of wastes occur extensively throughout south Florida's regional karst (Floridan) aquifer system. No comprehensive scientific investigation has been conducted to evaluate the influence of aquifer injections on SGD or associated environmentally sensitive resources such as corals and seagrass beds, in those near-shore waters. The results of this study provided the first evidence of ${ }^{4} \mathrm{He}$ excesses indicative of deep (Floridan) aquifer discharges in the ocean-side of the Florida Keys. The greatest ${ }^{4} \mathrm{He}$ excesses were in the Marquesas Keys, where localized coral decline and abnormally dense benthic macroalgae occurred, and in north Florida Bay, where 1987 seagrass dieoffs occurred. Benthic macroalgal samples from sites with dense macroalgal growth and localized coral decline had $\delta^{15} \mathrm{~N}$ ratios indicative of sewage: 1) where effluent disposal was concentrated in shallow-aquifer sewage effluent-injection wells, and 2) in the Marquesas Keys, 40 $\mathrm{km}$ from shallow-aquifer injection wells, septic tanks, and cess pits.

Surfacewater signatures indicative of aquifer-injection zones reconfirm breached aquifer confinement of the Floridan aquifer system. Remote Marquesas Keys sites with deep-aquifer signatures, extensive benthic macroalgal growth, and $\delta^{15} \mathrm{~N}$ signatures indicative of sewage effluent suggest a potential for effluent-laden SGD from aquifer injected sewage effluent, via fractures previously mapped in analog form by FDOT, to be a significant source of localized nutrients supporting harmful macroalgal blooms. Additionally, coral reefs exhibiting localized areas of decline in the upper and lower Upper Keys (Ball Buoy Reef and Cheeca Rocks, respectively), also had excessive growth of benthic macroalgae with $\delta^{15} \mathrm{~N}$ ratios that were indicative of human sewage. Those sites were located in proximity to the Ocean Reef and Cheeca Lodge Class V aquifer-injection wells, respectively and to the locations of georeferenced fractures identified after the study was designed and the samples were collected.

The locations of the fractures and fracture extensions shown in Figures 9 and 10A-C were not accessible for consideration at the time this study was initiated. Therefore, the study was not designed to evaluate the areas of those fractures and fracture extensions. The aquifer-injection facilities and wells identified in Table 2 and associated highlighted fractures shown in Figures 9 and 10A-C are not the only injection wells and fractures that may be contributing to surfacewater degredation in the coastal waters surrounding the Florida Keys. Other injection wells may be discharging in the study area at locations not evaluated in this study through fractures or sinuous dissolution features that may or may not be connected to the fractures shown in this study.

These data provide additional evidence of the nonhomogeneous, leaky-confinement of the underlying karst geology in the south Florida study area. These karst aquifer conditions are not conducive to the use of standard random, haphazard, and grid approaches for monitoring and sample collection. Factors that may be influencing these near-shore discharges are complex. They include the potential for shallow and deep aquifer-injected effluent to cause induced discharges of native (formation) ground water, as well as discharges of the injected effluent and co-mingled contaminants. The induced discharges may occur throughout the submerged carbonate platform, via fractures and other karst conduits and along the margin of the platform, where the contaminants can be re-distributed in near-shore and surfzone areas during upwelling events. These results provide a framework for future research, including groundwater tracer tests in injection wells and studies focusing on the vicinity of those fractures and fracture extensions in coastal waters surrounding the Florida Keys and other areas where injection wells are associated with fractures.

The Marine Protection, Research, and Sanctuaries Act required the initiation of a comprehensive and continuing program of monitoring and research regarding the dumping of material, such as sewage, into ocean waters or 
other coastal waters or their connecting waters within six months of October 23, 1972 (33 USC § 1441). Despite this federal requirement, no comprehensive and continuing monitoring and research of ocean, coastal and connecting waters has been initiated regarding discharges from aquifer-injection wells in south Florida. Immediate action to address this problem would include: 1) creating a central database with all of the essential information about these aquifer injections (e.g., the volume of injected fluids and the specific contaminants included in the injected fluids); 2) requiring tracer tests at any proposed new aquifer injection sites as part of the application review process to determine where the injected wastewater will resurface as SGD; and 3) requiring monitoring, such as the monitoring used in this study, for all existing and proposed aquifer injection wells to determine compliance with the antidegradation provisions of the CWA. Finally, the potential adverse impacts of these SGD on the $\sim 20$ environmentally sensitive federal and state "protected" areas in the vicinity, and the extent to which these discharges may be contributing to planktonic HABs, such as toxic red-tide events, also should be evaluated.

\section{Acknowledgments}

Assistance with logistics, sample collection or algal analysis was provided by Peter Barile, Larry Brand, Henry Feddern, Brian Lapointe, Don DeMaria, Thomas Warnke and Patrick Yananton. Analysis and interpretation of the groundwater tracer samples were provided by Zafer Top. Larry Brand provided his salinity and chl-a graphs of data and locations of vertical and horizontal transect sample points 1-24 from the Gulf of Mexico and the color graphic averages for salinity and chl-a in Florida Bay and oceanside along the coral reefs for the period during the dry season from 1996 to 2000. An anonymous donation provided funding for the boats and other logistical expenses for collection of the multidisciplinary samples and stable isotope analysis of the macroalgal samples. Isotopic analysis of the surfacewater samples collected during the study was funded, in part, by a grant from the Orlando, Palm Beach County, Sebastian Inlet, and South Florida Chapters of Surfrider Foundation. The Ecology Party of Florida provided funding for publication of the study results.

\section{References}

Anderson, D. M., Glibert, P. M., \& Burkholder, J. M. (2002). Harmful algal blooms and eutrophication: Nutrient $\begin{array}{llll}\text { sources, composition, and consequences. Estuaries, 25(4B), 704-726. } & \end{array}$ http://dx.doi.org/10.1007/Bf02804901

Arthur, J. D., Dabous, A. A., \& Cowart, J. B. (2002). Mobilization of arsenic and other trace elements during aquifer storage and recovery, southwest Florida. Paper presented at the US Geological Survey Artificial Recharge Workshop Proceedings.

Bacchus, S. T. (2000a). Predicting nearshore environmental impacts from onshore anthropogenic perturbations of ground water in the southeastern Coastal Plain, USA. Paper presented at the 3rd International Hydrology and Water Resources Symposium of the Institution of Engineers, Perth, Australia.

Bacchus, S. T. (2000b). Uncalculated impacts of unsustainable aquifer yield including evidence of subsurface interbasin flow. Journal of the American Water Resources Association, 36(3), 457-481. http://dx.doi.org/10.1111/j.1752-1688.2000.tb04279.x

Bacchus, S. T. (2001). Knowledge of groundwater responses - A critical factor in saving Florida's threatened and endangered species. Part I: Marine ecological disturbances. Endangered Species Update, 18(3), 79-90.

Bacchus, S. T. (2002). The "ostrich" component of the multiple stressor model: Undermining south Florida. In Porter, J.W., \& Porter, K. G. (Eds.), The Everglades, Florida Bay, and coral reefs of the Florida Keys: An ecosystem sourcebook (pp. 677-748). Boca Raton, FL: CRC Press.

Bacchus, S. T., \& Barile, P. J. (2005). Discriminating sources and flowpaths of anthropogenic nitrogen discharges to Florida springs, streams and lakes. Environmental \& Engineering Geoscience 11(4), 293-316, http://dx.doi.org/10.2113/11.4.347

Barile, P. J. (2004). Evidence of anthropogenic nitrogen enrichment of the littoral waters of east central Florida. Journal of Coastal Research, 20(4), 1237-1245. http://dx.doi.org/10.2112/04-0212.1

Bernardes, S., He, J., Bacchus, S. T., Madden, M., \& Jordan, T. (2014). Mitigation banks and other conservation lands at risk from preferential groundwater flow and hydroperiod alterations by existing and proposed Northeast Florida mines. Journal of Sustainable Development, 7(4), p225. http://dx.doi.org/http://dx.doi.org/10.5539/jsd.v7n4p225

Brand, L. E. (2002). The transport of terrestrial nutrients to south Florida coastal waters. In Porter, J.W., \& Porter, K. G. (Eds.), The Everglades, Florida Bay, and coral reefs of the Florida Keys: An ecosystem sourcebook 
(pp. 361-414). Boca Raton, FL: CRC Press.

Brand, L. E., \& Compton, A. (2007). Long-term increase in Karenia brevis abundance along the Southwest Florida Coast. Harmful Algae, 9, 620-635, http://dx.doi.org/10.1016/j.hal.2006.08.005

Brand, L. E., Pablo, J., Compton, A., Hammerschlag, N., \& Mash, D. C. (2010). Cyanobacterial blooms and the occurrence of the neurotoxin, beta-N-methylamino-L-alanine (BMAA), in South Florida aquatic food webs. Harmful Algae, 6, 232-252, http://dx.doi.org/10.1016/j.hal.2010.05.002

Clark, J. F. (2004). Time scale of seawater circulation and dolomitization within the lower Floridan aquifer. Paper presented at the Annual Meeting of the Geological Society of America, Denver, CO.

Clarke, W. B., Jenkins, W. J., \& Top, Z. (1976). Determination of tritium by mass-spectrometric measurement of He-3. International Journal of Applied Radiation and Isotopes, 27(9), 515-522. doi: 10.1016/0020-708x(76)90082-X

Clarke, W. B., \& Kugler, G. (1973). Dissolved helium in groundwater - possible method for uranium and thorium prospecting. Economic Geology, 68(2), 243-251.

Cunningham, K. J., Renken, R., Wacker, M., \& Zygnerski, M. (2003). Application of carbonate cycle stratigraphy to delineate porosity and preferential flow and to assess advective transport in the karst limestone of the Biscayne Aquifer. Paper presented at the Proceedings of GSA Annual Meeting and Exposition.

Enos, P., \& Perkins, R. D. (1977). Quaternary sedimentation in south Florida. Boulder, CO: Geological Society of America.

Fetter, C. W. (1988). Applied hydrogeology (2nd ed.). Columbus: Merrill Pub. Co.

Finkl, C. W., \& Charlier, R. H. (2003). Sustainability of subtropical coastal zones in southeastern Florida: Challenges for urbanized coastal environments threatened by development, pollution, water supply, and storm hazards. Journal of Coastal Research, 19(4), 934-943.

Florida Department of Environmental Protection. (2014). Underground injection control. Retrieved September 10, 2014, from http://www.dep.state.fl.us/water/uic/ and http://www.dep.state.fl.us/water/uic/index.htm

Florida Department of Transportation. (1973). Map of lineaments in the state of Florida. Tallahassee, FL.

Fourqurean, J. W., Durako, M. J., Hall, M. O., \& Hefty, L.N. (2002). Seagrass distribution in South Florida: A multi-agency coordinated monitoring program. In Porter, J.W., \& Porter, K. G. (Eds.), The Everglades, Florida Bay, and coral reefs of the Florida Keys: An ecosystem sourcebook (pp. 497-522). Boca Raton, FL: CRC Press.

Grobe, M., \& Bachu, S. (2004). The role of geological factors in determining the suitability of geological formations for long-term CO2 storage - examples from acid gas injection operations in western Canada. Paper presented at the Annual Meeting of the Geological Society of America, Denver, CO. Retrieved from http://gsa.confex.com/gsa/2004AM/finalprogram/abstract_75201.htm

Jordan, G. F. (1954). Large sink holes in straits of Florida. Aapg Bulletin-American Association of Petroleum Geologists, 38(8), 1810-1817.

Jordan, G. F., Malloy, R. J., \& Kofoed, J. W. (1964). Bathymetry and Geology of Pourtales Terrace, Florida. Marine Geology, 1(3), 259-287. http://dx.doi.org/ 10.1016/0025-3227(64)90063-5

Kaufman, M. I. (1973). Subsurface wastewater injection, Florida. Journal of the Irrigation and Drainage Division, 99(1), 53-70.

Kaufman, M. I., \& Mckenzie, D. J. (1975). Upward migration of deep-well waste injection fluids in Floridan aquifer, south Florida. Journal of Research of the United States Geological Survey, 3(3), 261-271.

Kincaid, T., Davies, G., Werner, C., \& DeHan, R. (2012). Demonstrating interconnection between a wastewater application facility and a first magnitude spring in a karstic watershed: Tracer study of the Southeast Farm Wastewater Reuse Facility, Tallahassee, Florida. Tallahassee, FL: Florida Geological Survey.

Kohout, F., \& Kolipinski, M. (1967). Biological zonation related to groundwater discharge along the shore of Biscayne Bay, Miami, Florida. In G. H. Lauff (Ed.), Estuaries (Vol. 83). Washington, DC: American Association for the Advancement of Science.

Krupa, S., \& Gefvert, C. (2005). Submarine groundwater discharge background and definitions of terms. In M. Schwartz (Ed.), Encyclopedia of Coastal Science (pp. 915-922): Springer Netherlands. 
Lapointe, B. E., \& Barile, P. (2001). Discrimination of nitrogen sources to harmful macroalgal blooms on coral reefs off southeast Florida Final report to the State of Florida Harmful Algal Bloom Task Force, 25.: Harbor Branch Oceanographic Institution.

Lapointe, B. E., Littler, M. M., \& Littler, D. S. (1987). A comparison of nutrient-limited productivity in macroalgae from a Caribbean barrier-reef and from a mangrove ecosystem. Aquatic Botany, 28(3-4), 243-255. http://dx.doi.org/10.1016/0304-3770(87)90003-9

Lines, J. P., Bernardes, S., He, J., Zhang, S., Bacchus, S. T., Madden, M., \& Jordan, T. (2012). Preferential groundwater flow pathways and hydroperiod alterations indicated by georectified lineaments and sinkholes at proposed karst nuclear power plant and mine sites. Journal of Sustainable Development, 5(12), p78. http://dx.doi.org/10.5539/jsd.v5n12p78

Littlefield, J. R., Culbreath, M. A., Upchurch, S. B. \& Stewart, M. T. (1984). Relationship of modern sinkhole development to large scale-photolinear features. In Beck, B.F. (Ed.), Proceedings of First Multidisciplinary Conference on Sinkholes, Orlando, Florida (pp. 189-195). A. A. Balkema Publishers, Accord, MA.

Lucier, A. M., Zoback, M. D., \& Gupta, N. (2004). The Ohio River Valley CO2 storage project: a geomechanical analysis. Paper presented at the Annual Meeting of the Geological Society of America, Denver, CO. Retrieved from https://gsa.confex.com/gsa/2004AM/finalprogram/abstract_79879.htm

Murphy, S. F., Verplanck, P. L., \& Barber, L. B. (2003). Comprehensive water quality of the Boulder Creek Watershed, Colorado, during high-flow and low-flow conditions, 2000. Denver, CO: U.S. Department of the Interior, U.S. Geological Survey.

National Oceanographic and Atmospheric Administration. (2001). Site characterization for Biscayne National Park: Assessment of Fisheries Resources and Habitats. Miami, FL: Southeast Fisheries Science Center.

National Research Council. Committee on the Causes and Managem.ent of Coastal Eutrophication. (2000). Clean coastal waters: understanding and reducing the effects of nutrient pollution. Washington, DC: National Academy Press.

Paul, J. H., McLaughlin, M. R., Griffin, D. W., Lipp, E. K., Stokes, R., \& Rose, J. B. (2000). Rapid movement of wastewater from on-site disposal systems into surface waters in the Lower Florida Keys. Estuaries, 23(5), 662-668. http://dx.doi.org/10.2307/1352892

Paytan, A., Shellenbarger, G. G., Street, J. H., Gonneea, M. E., Davis, K., Young, M. B., \& Moore, W. S. (2006). Submarine groundwater discharge: An important source of new inorganic nitrogen to coral reef ecosystems. Limnology and Oceanography, 51(1), 343-348. http://dx.doi.org/10.4319/lo.2006.51.1.0343

Popenoe, P., Kohout, F., \& Manheim, F. (1984). Seismic-reflection studies of sinkholes and limestone dissolution features on the northeastern Florida shelf. Paper presented at the Proceedings of First Multidisciplinary Conference on Sinkholes, Orlando, FL.

Price, R. E., \& Pichler, T. (2004). Arsenic and ASR in Southwest Florida: source, abundance, and mobilization mechanism Suwannee Limestone, Upper Floridan Aquifer. Paper presented at the Aquifer Storage Recovery IV. Science, Technology, Management and Policy, Tampa, FL Retrieved from http://www.dep.state.fl.us/geology/geologictopics/asr4/posters/Price.pdf

Pyne, R. D. G., McNeal, M. B., \& Horvath, L. E. (2004). Analysis of arsenic occurrence and attenuation in thirteen operational ASR wellfields in the Floridan and Hawthorn aquifers. Palatka, FL.: Florida Department of Environmental Protection. St. Johns River Water Management District.

Raabe, E. A., \& Bialkowska-Jelinska, E. (2010). Thermal imaging of the Waccasassa Bay Preserve: image acquisition and processing: United States Geological Survey,

Reese, R. S. (2002). Inventory and review of aquifer storage and recovery in southern Florida. Tallahassee, FL; Denver, CO: United States Department of the Interior; United States Geological Survey.

Rosenberry, D. O., Striegl, R. G., \& Hudson, D. C. (2000). Plants as indicators of focused ground water discharge to a northern Minnesota lake. Ground Water, 38(2), 296-303. doi: 10.1111/j.1745-6584.2000.tb00340.x

Schreiber, M. E., Valett, H. M., Brown, B. V., \& Altare, C. (2004). Evaluating arsenic transport within anthropogenic aquifers in mined watersheds. Paper presented at the Annual Meeting of the Geological Society of America, Denver, CO. Retrieved from https://gsa.confex.com/gsa/2004AM/finalprogram/abstract_74773.htm 
Smith, N. P. (1981). An investigation of seasonal upwelling along the Atlantic coast of Florida. Elsevier Oceanography Series, 32, 79-98.

Smith, N. P. (1982a). Response of Florida Atlantic shelf waters to hurricane David. Journal of Geophysical Research-Oceans and Atmospheres, 87(Nc3), 2007-2016. http://dx.doi.org/10.1029/Jc087ic03p02007

Smith, N. P. (1982b). Upwelling in Atlantic shelf waters of South Florida. Florida Scientist, 45(2), 117-125.

Smith, N. P. (1983). Temporal and spatial characteristics of summer upwelling along Florida's Atlantic shelf. $\begin{array}{lllll}\text { Journal of } & \text { Physical 1709-1715. }\end{array}$ http://dx.doi.org/10.1175/1520-0485(1983)013<1709:Tascos>2.0.Co;2

Starr, R. C., Green, T. S., \& Hull, L. C. (2001). Evaluation of confining layer integrity beneath the south district wastewater treatment plant, Miami-Dade Water and Sewer Department, Dade County, Florida: INEEL/EXT-2001-00046, Idaho National Engineering and Environmental Laboratory, Idaho Falls, ID.

Top, Z., Brand, L. E., Corbett, R. D., Burnett, W., \& Chanton, J. (2001). Helium and radon as tracers of groundwater input into Florida Bay. Journal of Coastal Research, 17(4), 859-868.

Top, Z., Eismont, W. C., \& Clarke, W. B. (1987). Helium isotope effect and solubility of helium and neon in distilled water and seawater. Deep-Sea Research Part a-Oceanographic Research Papers, 34(7), 1139-1148. http://dx.doi.org/10.1016/0198-0149(87)90068-9

United States Army Corps of Engineers. (2004a). Central and Southern Florida Project Comprehensive Everglades Restoration Plan: Vol. 1 - Final Aquifer Storage and Recovery Pilot Project Design Report Lake Okeechobee ASR Pilot Project, Hillsboro ASR Pilot Project, Caloosahatchee (C-43) River ASR Pilot Project, $\sim 200+$ Appendices.

United States Army Corps of Engineers. (2004b). Central and Southern Florida Project Comprehensive Everglades Restoration Plan: Vol. 2 - Final Environmental Impact Statement - Lake Okeechobee ASR Pilot Project, Hillsboro ASR Pilot Project, Caloosahatchee (C-43) River ASR Pilot Project, $184+$ Appendices.

United States Environmental Protection Agency. (1983). Appendix A to Chapter 2 - General Program Guidance (antidegradation), Water Quality Standards Handbook. Retrieved from http://water.epa.gov/ scitech/swguidance/standards/upload/2006_12_01_standards_antidegqa.pdf.

United States Environmental Protection Agency. (1997). Miami-Dade County Administrative Order of Consent No. 4UICC-006-95.

United States Environmental Protection Agency. (2000). Revision to the federal underground injection control (UIC) requirements for Class 1 - municipal wells in Florida. Federal Register, 65(131), 42234-42245.

United States Environmental Protection Agency. (2003). Relative risk assessment of management options for treated wastewater in south Florida. EPA, 816-R-03-010.

Vega Thurber, R. L., Burkepile, D. E., Fuchs, C., Shantz, A. A., McMinds, R., \& Zaneveld, J. R. (2014). Chronic nutrient enrichment increases prevalence and severity of coral disease and bleaching. Global Change Biology, 20, 544-554. http://dx.doi.org/10.1111/gcb.12450

White, D. E. (1957). Magmatic, connate, and metamorphic waters. Geological Society of America Bulletin, 68(12), 1659-1682. http://dx.doi.org/10.1130/0016-7606(1957)68[1659:Mcamw]2.0.Co;2

Wilson, W. E., \& Moore, J. E. (1998). Glossary of hydrology. Alexandria, Va.: American Geological Institute.

Yassin, R. R., Muhammad, R. F., Taib, S. H., \& Al-Kouri, O. (2014). Application of ERT and aerial photographs techniques to identify the consequences of sinkholes hazards in constructing housing complexes sites over karstic carbonate bedrock in Perak, peninsular Malaysia. Journal of Geography and Geology, 6(3), p55. http://dx.doi.org/10.5539/jgg.v6n3p55

\section{Copyrights}

Copyright for this article is retained by the author(s), with first publication rights granted to the journal.

This is an open-access article distributed under the terms and conditions of the Creative Commons Attribution license (http://creativecommons.org/licenses/by/3.0/). 